\title{
Strait of Istanbul, major accidents and abolishment of left-hand side navigation
}

\author{
Cahit İstikbal
}

Cite this article as:

İstikbal, C. (2020). Strait of Istanbul, major accidents and abolishment of left-hand side navigation. Aquatic Research, 3(1), 40-65. https://doi.org/10.3153/AR20005

Turkish Maritime Safety Association, Maritime Transportation and Management Engineer and Chief Pilot for the Turkish Straits and the Port and Harbours of İstanbul, Turkey

ORCID IDs of the author(s): C.İ. 0000-0002-5020-1025

Submitted: 29.10 .2019

Revision requested: 22.11 .2019

Last revision received: 01.12 .2019

Accepted: 01.12.2019

Published online: 26.12.2019

Correspondence:

Cahit İSTIKBAL

E-mail: cahit@istikbal.org

\begin{abstract}
Strait of Istanbul is one of the most difficult waterways in the world. It's curved structure, sharp bends which require 12 major course alterations form a unique marine environment for passing vessels. Currents also form a natural difficulty for navigation, especially at areas at the North of Kandilli point. There are three types of currents prevail in the Strait of Istanbul: the first is the surface currents, which finds it's dynamics at the difference of sea levels between Sea of Marmara and Black Sea. Due to this difference in levels, which is around 40 centimeters on average and fed by the rivers flowing into Black Sea, waters run down to Sea of Marmara and to outer seas. Second, is the counter currents and eddies inside the bays. Third is the subsurface currents, formed by the difference of salinity between Marmara and Black Sea, starts from 10 meters to 40 deep and in counter direction with the surface currents. To make this currents system more complicated, in the case of strong SW winds when lasted more than 2-3 days, the whole currents system changes when the surface currents reversed by the wind and above-mentioned difference in sea levels exchange positions to the favor of Sea of Marmara. Due to this unique system of currents, Strait of Istanbul used to have a unique navigational system, too. Starting from ancient times, ships navigating in the Strait of Istanbul used to navigate on the Port side, especially when navigating from Sea of Marmara to Black Sea direction. Thus, ships could get better protection against current. This practice was inked on the paper in 1933 and by the Istanbul Port Regulation through which it became compulsory for ships navigating in the Strait of Istanbul. But as the international regulations on the preventing collision at sea emerged and it appeared that right-hand navigation was established for narrow channels and altering the course to Starboard in the headon situations has become a rule, the Left-hand side navigation in the Strait of Istanbul started to lead to confusion. There have been three major accidents in the Strait of Istanbul which could be attributed to confusion created by this national rule against the international rule; in 1960, 1966 and 1979, finally Left-hand side navigation in the Strait of Istanbul was abolished in 1982. This article is about these long-term proceedings of Left-hand side navigation in the Strait of Istanbul, concentrating on and analysing three major accidents.
\end{abstract}

Keywords: Strait of Istanbul, Left-hand side navigation, Thalweg line, Turkish Straits, Collision Regulations, Maritime safety

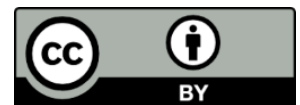

(C) Copyright 2020 by ScientificWebJournals Available online at

http://aquatres.scientificwebjournals.com 


\section{Introduction}

It has been said that a wise man learns from his own experience but a wiser man learns from the experience of others. However, in maritime field, all roads lead to Rome. Every single accident affects all others in the maritime domain. Resulting cost is high and losses are often indispensable. Maritime sector has learnt a lot from the accidents and, during a century, was used to be reactive. It took too long to change this approach. Therefore, the concept of proactive approach with regard to maritime accidents is comparatively new. Preventive measures used to be taken after the accidents, as it was the case with Titanic, Torrey Canyon, Amoco Cadiz accidents and a number of others. Towards the end of 1990's, especially after the Erika (1999) and Prestige (2002) accidents, a proactive/preventive approach started to emerge. Because it was clearly understood, that waiting for an accident to happen to take the lessons costed the indispensable loss of human life as well as vast amount of natural and environmental resources.

With that background, looking at the Strait of Istanbul, we see both reactive and proactive periods with regard to safety measures that has been taken. Proactive period begins after 2000 's especially when one-way traffic has been established in 2006 in the absence of a major accident. Reactive period began with the Independenta accident (1979) and continued with Nassia-Shipbroker accident (1994) the first resulted in the establishment of right-hand navigation in accordance with COLREG Rule 9 and te latter resulted in the entry into force of Turkish Straits Maritime Traffic Regulations. The subject of this article is three major accidents that took place including the Independenta accident, which ranked the $9^{\text {th }}$ in the world with regard to amount of oil spilt, and the maritime safety measures took effect following this accident. A common ground was found between these three accidents, which was, a conflict between national and international rules, in which, national rules ordered to alter the course to port in head-on confrontations and international rules ordered the contrary. This article aims to analyze these accidents and set forward whether this conflict played a role in the collisions.

\section{Materials and Methods}

Related accidents and maritime safety, field studies, past maritime pilotage experience of the researcher set the groundwork for this study. Three major accidents occurred in the Strait of Istanbul has been analysed to find out their relation with the left-hand side navigation which was in use in pre-1982 era. The ships involved in these accidents has been applied with the same criteria in order to find out the root causes of the accidents. ISailor Electronic Navigational
Charts were used in order to obtain nautical data and positions. The accidents have been approached by taking the human element into account as a primary figure and due to this approach and in order to create a perception of empathy, a story-telling style presided in the wording. In analysing the three major accidents, a controversial common ground was found; which was the head-on situation at the encounter before each accident. The actions of encountering vessels were analysed and findings were left for discussion.

\section{Reactive and Proactive Approaches in Maritime Safety}

General maritime law was first codified in 2000 B.C within the Hammurabi Code and at that time, accidents were accepted as the act of gods (İstikbal, 2012). Towards the end of the 19th century, conversation took place between the main sea-related nations, such as Great Britain and France, especially to establish common rules for accident avoidance in the English Channel (Soltani, 2009). The first maritime measures regarding the maritime safety took place after the Titanic accident, 1912, after which the first international conference convened and led to the first International Maritime Convention, SOLAS 1914, and enforced in 1919. Another example was the M/T Torrey Canyon accident, in 1967, a tanker, which ran aground, while entering the English Channel and spilled her entire cargo of 120,000 tons of crude oil into the sea. This was the biggest oil pollution incident ever recorded up to that time (IMO, 2019). And, in consequence, IMO Legal Committee was created in 1967, CLC Convention and International Convention related to the Intervention on the High Seas in Cases of Oil Pollution Casualties were concluded in 1969 followed by Fund Convention in 1971 and MARPOL Convention in 1973. M/T Exxon Valdez case was another major accident that was led to legislative measures. The tanker went aground in the Prince William Sound in Alaska in 1989, caused the spill of the 37,000 tons of crude oil -almost one fifth of her whole cargo, which was 162.000 tons. This was the largest oil spill in US waters until that date. Subsequently, US Oil Pollution Act was enforced in August 1990, MARPOL amendments were made in March 1992 which brought double hull standard for new building tankers and a phase out period for the existing single hull tankers. Erika and Prestige tanker disasters, in 1998 and 2002 respectively, which were caused to 20.000 tons and 63.000 tons of oil spilt into Atlantic Ocean off Spanish and French coasts, alerted the European Union to take specific measures. Resulting actions were the ERIKA 1 and ERIKA 2 packages in March \& December 2000, Phase out of single-hull tankers, creation of European Mari- 
time Safety Agency (EMSA), reinforcement of Port State Control system (PSCs), adoption of FUND II in 2003, preparing of EU ERIKA 3 Package, in December 2008, set up ship-owners and Flag States obligation in the event of oil pollution.

All examples given above indicate that the approach of maritime sector with regard to maritime safety during these periods was reactive. However, with the beginning of the $21^{\text {st }}$ century, a new approach has emerged led by the International Maritime Organization. Instead of waiting for accidents to happen and take steps afterwards, IMO decided to be proactive and started to review its framework accordingly. In 2002, IMO adopted the "Guidelines for Formal Safety Assessment (FSA) for use in the IMO rule-making process". FSA was, as described by IMO, "A process used for ensuring that action is taken before a disaster occurs". It is a structured and systematic methodology, aimed at enhancing maritime safety, including protection of life, health, the marine environment and property, by using risk analysis and cost benefit assessment. A new era has begun, and member countries were encouraged to report all near misses and incidents in order to assist to bringing-to-life of this new approach.

\section{Left-Hand Side Navigation in the Strait of Istanbul}

\section{Currents}

The Strait of Istanbul has unique characteristics. Located between the Black Sea and the Sea of Marmara, it is a waterway 32 kilometers in length and with an average width of 1.5 kilometers. The length of its coasts measures $55 \mathrm{~km}$ on the European side and $35 \mathrm{~km}$ on the Asian side (İstikbal, 2001). From this, we can see that the European coast is $36 \%$ longer and comparatively more indented. This is also one of the indirect factors for currents being more effective on the Asian side.

The axis passing from the mid-points at both ends of the Strait forms an angle of 25 degrees from Geographical North. The air route over the strait is 025 degrees towards the Black Sea and 205 degrees towards the Sea of Marmara. These routes are also the average of total passing routes of ships in the Strait. If we convert this to wind direction, it is the NE-SW axis-which are the prevailing winds in the Strait. This is a factor for accelerating the southerly currents and The extra supply of water in the Black Sea by rivers produces a difference in the sea level between the northern and southern ends of the Strait, due to which a constant current occurs; but in this channel, from its having seven sharp bends, counter-currents and eddies are formed on either shore, as in a river.

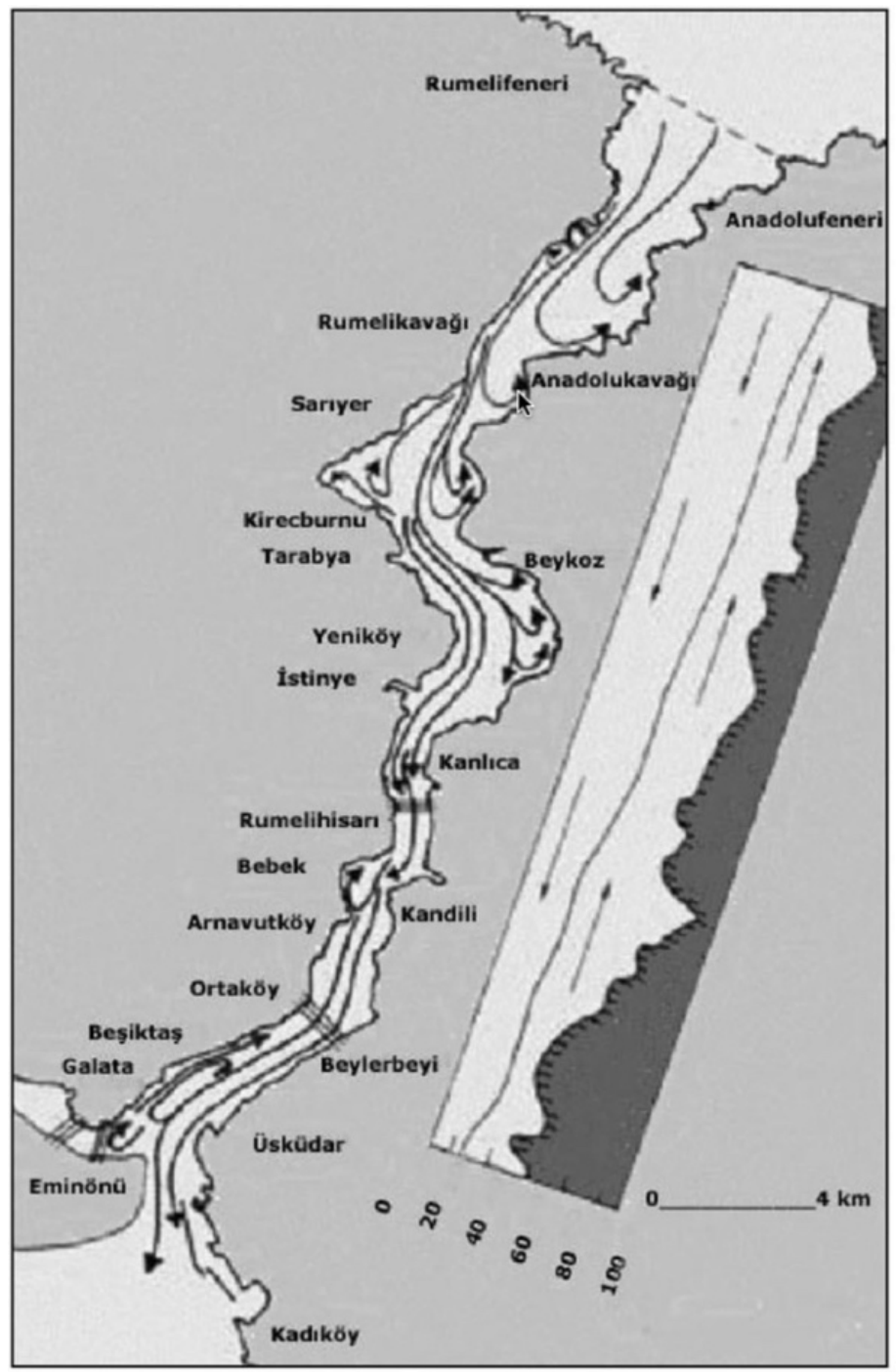

Figure 1. Surface and subsurface currents at the Strait of Istanbul (Seyir Hidrografi ve Oşinografi Dairesi Başkanlığı)

The currents in the Strait of Istanbul have a fast response to sea level differences between the Black Sea and the Mediterranean (Özsoy et al, 2002). Black Sea is about 40 centimeters higher than the Sea of Marmara and 60 centimeters higher than the Aegean. Within the two-layer current system in the Strait of Istanbul, this difference in the water levels at both ends constitute an upper current which has an average speed of 3-4 Knots towards the Sea of Marmara (Figure-1). The lower layer is about a half compared to the upper layer, with regard to velocity and volume of the water transferred (Figure-2). 
ANNUAL

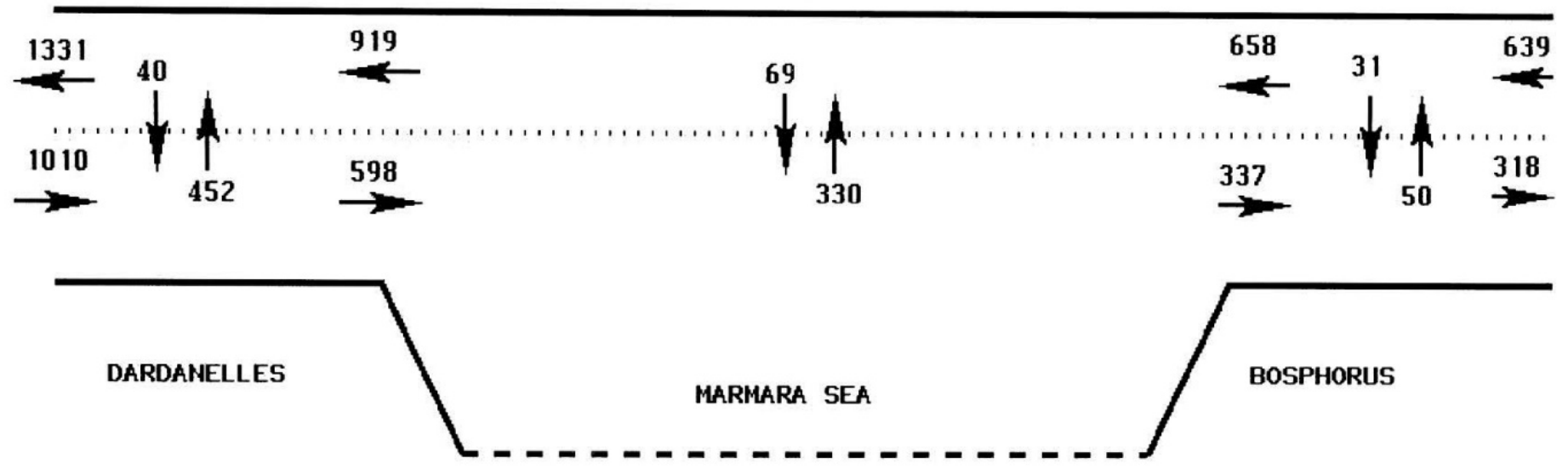

Figure 2. Annual volume fluxes ( $\mathrm{km}^{3} /$ year) across the compartments of the Sea of Marmara and straits (Tuğrul et al. 2002).

Contributions of precipitation and river runoff are of nearly equal volume (300 and $320 \mathrm{~km}^{3} / \mathrm{yr}$ respectively), totaling a fresh water input to Black Sea which is about twice as large as the evaporation $\left(350 \mathrm{~km}^{3} / \mathrm{yr}\right)$ (Ünlüata et al., 1990). As the only water output to high seas, Black Sea sends this water through the Strait of Istanbul first, via upper layer, which forms a height difference of water on either side. The warm and more saline lower layer, called Mediterranean water, flows towards the Black Sea. These two layers, despite a neutral area they have in between, do interact and this interaction is indicated in the Figure 2. The upper and lower layers constitute the current dynamics of the Istanbul Strait in. particular, and the Turkish Straits system in general. From the aspect of maritime transportation, the lowerlayer is negligible with regard to its effect to the passing vessels. Upper layer is what this article interested about. Surface currents, which can increase up to 6-8 knots in speed, are one of the most important handicaps for navigation through the Straits (İstikbal, 2006).

By analyzing Figure 1, we can find out that the currents will be more effective in the Asian side in certain parts of the Strait of Istanbul, because diverting arms such as TarabyaYeniköy area and Bebek Bay-Akınt1 Burnu area directs the current towards the Asian shores. In fact, Strait of Istanbul can be divided in two main parts: The Southern Part and the Northern Part. Kandilli Point can be appointed as a dividend between these two. From the holistic perspective, it can be said that surface (upper layer) currents are more effective for navigating vessels in the Southern part compared to the Northern part.

The dominant current system is effective most of the yearin the case of prevailing NE winds. But in the Istanbul Strait, SW winds are also effective in certain periods of the year. When SW winds are effective, the current regime changes a lot throughout the Strait. There has been a number of accidents in the existence of strong SW winds and northerly currents (Locally called Orkoz) in the Strait. Petar Zoranic-World Harmony, Nassia-Shipbroker accidents are some dramatic examples.

\section{Left-hand side Navigation in the Strait of Istanbul}

Experienced navigators and local pilots, as far as regulations allowed, used to take advantage of the currents in the Strait of Istanbul. When they entered the Strait of Istanbul from Sea of Marmara, North bound, they used to cross towards European shores after having passed abeam Kizkulesi (Maiden's Tower). Let's take a Northbound vessel passing through the Strait as an example. The ship must struggle with the strong current off Haydarpaşa Breakwater first. Experienced captains would approach the starboard side after passing the breakwater lighthouse. Here the current is neutral or more or less northbound. However, strong currents take over the ship again abeam of Maiden's Tower literally pushing the ship from the starboard side. From 1934 until 1982, ships used to cross directly towards Ortaköy from this point. After crossing the Maiden's Tower, they would alter course to the opposite shore. This was because currents which are strong on the Anatolian shores were weak on the European side. In fact, a reverse current close to the coastline at Dolmabahçe and Beşiktaş leans towards Ortaköy and Galatasaray Island up to the Akıntı Burnu, or Hermaion Point as it is known in mythology. Following this route can save up to 45 minutes in a Strait passage. That was probably how Left-hand side navigation emerged in the Strait of Istanbul. Officially remained in force between 1934-1982, left hand navigation used to $b$ e known as themost convenient method of passage for ships in order to minimize the effect of counter currents. Figure-3 indicates 
the Left-hand side side passage system that remained in force between 1934 and 1982. There were 2 areas where ships crossed from one shore to the other. For north-bound passage, the first crossing was starting in front of Kizkulesi (Maiden's Tower) ending at Ortaköy area where Left-hand side navigation should have fully confirmed, and other was starting in front of Tarabya bay ending at Umuryeri Banks, where return to right-hand navigation took place. For South bound passage, the same crossings were held in vice versa.

So far, it has been emphasized that Left-hand side navigation was very convenient with natural and morphological conditions of the Strait, especially upper currents. One question may arise: was it voluntary for passing ships to take this advantage or were there any rules making this system compulsory to comply with? The answer is the latter. The regulations regarding the Left-hand side navigation were as follows in chronological order:

1. Istanbul Port Regulation (07 August 1933): According to this regulation, in contrast with righthand side navigation, which was in force in most Straits of the world, Left-hand side side was established in the Strait of Istanbul (Oğuzülgen, 2016). New Istanbul Port Regulation drafted to replace the Istanbul Port Ordinance and this new Regulation was was published on the Official Gazzette no. 2471 in 25 July 1933 and entered into force. According to Article 62 of this new Regulation, effective date of Article 17, which was regarding to Lefthand side Traffic, would be 6 months later. The mentioned Article 17 of 1933 Regulation was as follows:

"Article 17: Whenever possible and safe from the danger, all ships crossing the Black Sea Strait towards the Black Sea will navigate on the the Port side of the Bosphorus, which means Rumeli side, and the the ships from the Black Sea, will navigate on the starboard, which means on the Anatolian side. Article 25 of the Regulations for Preventing Collision at Sea shall not be applied on the Bosphorus. Şirketi Hayriye ships will navigate according to the berths where they will stop by."

This new regulation, which established Left-hand side navigation in the entire Strait, entered into force on 25 February 1934.

2. Decision of the Council of Ministers (11 October 1934): Implementation of Left-hand side in the entire Strait formed a full contradiction with the Regulations for Preventing Collision at Sea, due to which, the Council of Ministers revisited and amended the Article 17 of Istanbul Port Regulation in 1934. According to the amended Article 17, the former Article 17 (above) remained the same as Paragraph 1 and the following Paragraph was added as Paragraph 2:

"Article 17: The application area of this article is between the line connecting Kizkulesi and Ortaköy Mosque in the South and the line connecting Kireçburnu Lighthouse to Umuryeri Bank Lighthouse in the North. Apart from this field, the Regulations for Preventing Collision at Sea are applied. The ferries to visit the piers on the shores of this area navigate according to the piers to be visited."

According to 1934 amendment, the Left-hand side navigation in the Strait of Istanbul was limited to a certain area, namely between Kizkulesi and Ortaköy Mosque in the South and Kireçburnu Lighthouse to Umuryeri Bank Lighthouse in the North (Oguzülgen, 2016). In the rest of the Strait, the appropriate rules of the Preventing Collision of the Sea for right hand navigation in a channel were to be applied. The coverage area of Left-hand side navigation consisted only a few miles less than the half of the total length of the Strait (7 out of 18 Miles).

3. Istanbul Port Regulation (25 December 1965) : The 1934 Port Regulation needed an update after 21 years of experience. With a new regulation which was announced by the Decision of Council of Ministers on 19 November 1965 and entered into force by publishing on the Official Gazette No. 12186 on 25 December 1965, some new measures were introduced as well as some articles of the previous Regulations were amended. As for the new measures, the speed limit for passing ships was set to 10 knots (Art. 29), fishing was prohibited (Art. $44 \& 45$ ) the local traffic ordered not to impede and keep out the way of passing non-stopover traffic through the Strait (Art. 27) and a change was made on the application limits of Left-hand side traffic system (Article 26). The related article of the new regulations wea as follows:

"Article 26: Ships passing towards North through the Strait of Istanbul will proceed on the Left-hand side of the thalweg (median) line in the Strait (European Side) and South-bound ship passing towards Marmara direction will proceed on the Left-hand side (Asian side) of the thalweg line. This rule will be applied between the line from Kizkulesi to Ortaköy 
Mosque in the South and the line between Tarabya Point to Umuryeri Bank in the North."

The Article 26 of 1966 Regulation had no big difference from the Article 17 of 1934 regulation; the Kireçburnu Point in the 1934 regulation was changed to Tarabya Point, which was only 3 cables in the NW. So we can assume that the Left-hand side navigation was kept as it was in the 1965 Regulation.

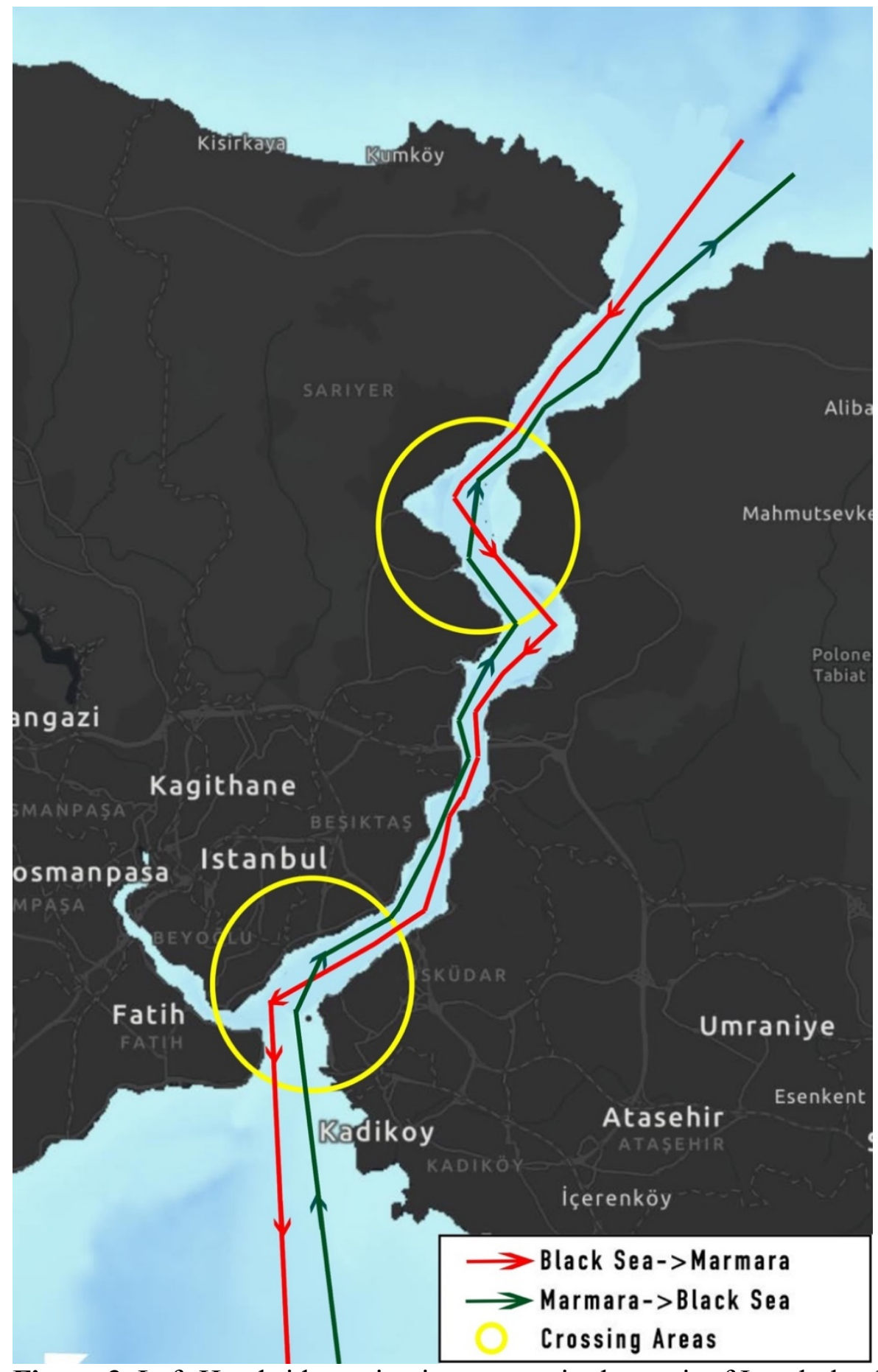

Figure 3. Left-Hand side navigation system in the strait of Istanbul, which remained in force between 1934-1982 


\section{Accidents in Strait of Istanbul: From Inactivity to Reactive and Proactive Periods}

Several maritime accidents happened in the Strait of Istanbul before the most extensive set of regulations put into effect in 1994. Tragic accidents began in 1960 with Peter Zoranic-World Harmony collision after which no action was taken and continued with M/T Lutsk-M/V Cransky Oktiabr collision in 1966, after which no action was taken either. The latter was obviously due to Left-hand side navigation that was in effect in the Strait and that was pointed out in the statement of Captains after the accident. However, termination of this application (Left-hand side navigation) took 16 more years and finally COLREG Rule 9 for narrow straits was implemented in 1982.
The maritime accidents and their subsequent reflections in the maritime safety measures are shown in Table 1.

\section{M/T Peter Zoranic- M/T World Harmony Collision}

a. Accident: On August 27, 1960, the shipyard "III Maj" delivered the tanker "Petar Zoranic" to Yugoslav Tanker Ship, the Government company of Yugoslavia. It was named after the Croatian writer Petar Zoranic, author of the first Croatian novel, The Mountain (Kvaternik, 2018). It was launched on September 20, 1959. Her IMO number was 5613855, GT 17.830, and she was carrying 25,400 tonnes. He was enlisted in the fleet of the Zadar shipping company "Jugotanker", today's "Tankerska plovidba", on September 27, 1960. The tanker "Petar Zoranic" was the largest ship built in Yugoslavian shipyards until 1960.

Table 1. Major Accidents in the strait of Istanbul and counter measures

\begin{tabular}{|c|c|c|c|c|c|}
\hline \multicolumn{6}{|c|}{ Maritime Accidents in The Strait of Istanbul And Subsequent Safety Measures } \\
\hline Accident & Type\&Date & Location & Possible Cause & Result & Resulting Action \\
\hline $\begin{array}{l}\mathrm{M} / \mathrm{T} \text { Petar } \\
\text { Zoranic } \\
\text { M/T World } \\
\text { Harmony }\end{array}$ & $\begin{array}{l}\text { Collision } \\
14 / 12 / 1960\end{array}$ & Kanlica & Left Hand Navigation & $\begin{array}{l}52 \text { Lives Lost } \\
22.000 \text { Tons of } \\
\text { Oil Spilt }\end{array}$ & $\begin{array}{l}\text { No measures were } \\
\text { taken }\end{array}$ \\
\hline $\begin{array}{l}\text { M/T Lutsk } \\
\text { M/V Cransky } \\
\text { Oktiabr }\end{array}$ & $\begin{array}{l}\text { Collision } \\
01 / 03 / 1966\end{array}$ & $\begin{array}{l}\text { Maiden's } \\
\text { Tower }\end{array}$ & Left Hand Navigation & $\begin{array}{l}12.000 \text { Tons of } \\
\text { Oil Spilt }\end{array}$ & $\begin{array}{l}\text { No measures were } \\
\text { taken }\end{array}$ \\
\hline $\begin{array}{l}\text { M/V Evriali } \\
\text { M/T Independenta }\end{array}$ & $\begin{array}{l}\text { Collision } \\
15 / 09 / 1979\end{array}$ & $\begin{array}{l}\text { Near } \\
\text { Haydarpaşa } \\
\text { Breakwater }\end{array}$ & $\begin{array}{l}\text { Left Hand Navigation/ } \\
\text { Pilot Embarka- } \\
\text { tion/Disembarkation } \\
\text { Locations }\end{array}$ & $\begin{array}{l}90.000 \text { Tons of } \\
\text { oil spilt \& } \\
\text { burned }\end{array}$ & $\begin{array}{l}\text { Left hand navigation } \\
\text { terminated-COLREG } \\
\text { Rule } 9 \text { for narrow } \\
\text { channels established. }\end{array}$ \\
\hline $\begin{array}{l}\text { M/V Shipbroker } \\
\text { M/T Nassia }\end{array}$ & $13 / 03 / 1994$ & $\begin{array}{l}\text { Northern } \\
\text { Entrance/In } \\
\text { front of } \\
\text { Kavak Point }\end{array}$ & $\begin{array}{l}\text { Not suspension of } \\
\text { traffic/Pilot Embarkation- } \\
\text { Disembarkation Locations }\end{array}$ & $\begin{array}{l}9.000 \text { Tons of } \\
\text { crude oil spilt\& } \\
20.000 \text { tons of } \\
\text { Crude Oil burnt }\end{array}$ & $\begin{array}{l}\text { Suspension of traffic } \\
\text { during passage of large } \\
\text { tankers/Turkish Straits } \\
\text { Maritime Traffic } \\
\text { Regulations/IMO } \\
\text { approved COLREG } \\
\text { Rule } 10 \\
\text { implementation }\end{array}$ \\
\hline
\end{tabular}

Milestone maritime accidents in the Strait of Istanbul and subsequent actions taken 
Table 2. MT Petar Zoranic/MT World Harmony ship characteristics

\begin{tabular}{|l|l|l|}
\hline & $\begin{array}{l}\text { M/T Petar Zoranic } \\
\text { (South-Bound) }\end{array}$ & $\begin{array}{l}\text { M/T World Harmony } \\
\text { (North-Bound) }\end{array}$ \\
\hline Date-Place Built & $\begin{array}{l}\text { 1960-Yugoslavia (BRODOGRADILISTE } \\
\text { III MAJ, Rjeka, Croatia) }\end{array}$ & $\begin{array}{l}\text { 1954-UK (Vickers-Armstrong Ltd., } \\
\text { Barrow-In-Furness) }\end{array}$ \\
\hline Owner & $\begin{array}{l}\text { Jugoslavenska tankerska plovidba } \\
\text { (Jugotanker) }\end{array}$ & Stavros Niarchos Ltd., London \\
\hline Type \&Flag & Tanker-Yugoslavian & Tanker-Greek \\
\hline Pilot Onboard & Yes- Capt. Cevdet Çubukçu & No \\
\hline Cargo & $\begin{array}{l}\text { Fully Laden Gasoline: } 12.000 \text { T \& Diesel } \\
\text { Oil: } 11.330 \text { T }\end{array}$ & No Cargo-Dirty Ballast \\
\hline DIMENSIONS (Lxbxd) & $192.4 x 25 x 9.8 \mathrm{~m}$ & $202.1 \times 26.4 \times 10.5 \mathrm{~m}$ \\
\hline Tonnage & 17830 GT & 20992 GT \\
\hline Max.Speed & 17.5 Knots & 15.5 Knots \\
\hline Engine \& Propeller & Steam Turbine, Single Screw & Steam Turbine, Single Screw \\
\hline
\end{tabular}

She ended its voyage forever in a horrific fire on December 14, 1960, the 108th day of navigation. On December 13, 1960, "Petar Zoranic" departed from the Black Sea port of Tuapse, loaded the cargo into the front tanks of 12,000 tons of gasoline and into the stern tanks of 11,330 tons of diesel fuel. The tanker was under command of Capt. Anton Sablic from Kostrena. It was about 01:00 O'Clock, just starting of the day of $14^{\text {th }}$ December, 1960, when tanker Petar Zoranic arrived at the Northern entrance of the Strait of Istanbul, where she picked up a local pilot. Capt. Cevdet Çubukçu was the pilot who climbed up the ladder extended from the tanker. Born on 1 October 1926 and started his maritime business after secondary school Capt. Cevdet Çubukçu was just 34 years old at that time. Having worked on vessels named Kaptan Uzunoğlu and Hatay owned by DB Cargo Lines, he had begun his pilotage career in 1955 . He was almost at the beginning of his pilotage career when he got onboard M/T Petar Zoranic. And it was an extraordinary day in the Strait. Because strong Southern winds were prevailing in Istanbul since a couple of days which provoked a reverse current in the Strait that reached to 5 knots under the effect of continuous winds which exchanged the sea level difference on advantage of Marmara coast and higher waters of Marmara started to run towards the lower level waters of Black Sea with wind helping by pushing the surface waters. This was the reverse current which locally called as "Orkoz". Orkoz always created a different current regime in the Strait, making the navigation more difficult. And, in 1994 Regulations, traffic started to be suspended when Orkoz currents exceeded 4 knots of speed. At that day, it was 5 knots, but unfortunately, at that time period, there was no regulation existed to suspend the traffic in the Strait. So, tanker Petar Zoranic entered the Strait, picked up the pilot at Kavak point, upon arriving on the bridge, Capt. Cevdet Çubukçu and Capt. Anton Sablic shaked hands, conning of the ship -most probably- delivered to pilot and passage through the Strait commenced. Soon after, the tanker arrived to Köybaşı point, which required the sharpest turn-about 80 degrees- in the Strait, and after the turn completed, started to move towards Kanlica point on the Asian shores as she should follow the Left-hand side side of the Strait due to Port Regulations. At that time, a marginally larger tanker, M/T World Harmony, was proceeding to North. She was under ballast, without cargo, but her tanks were not gas free which meant they were prone to an explosion. 


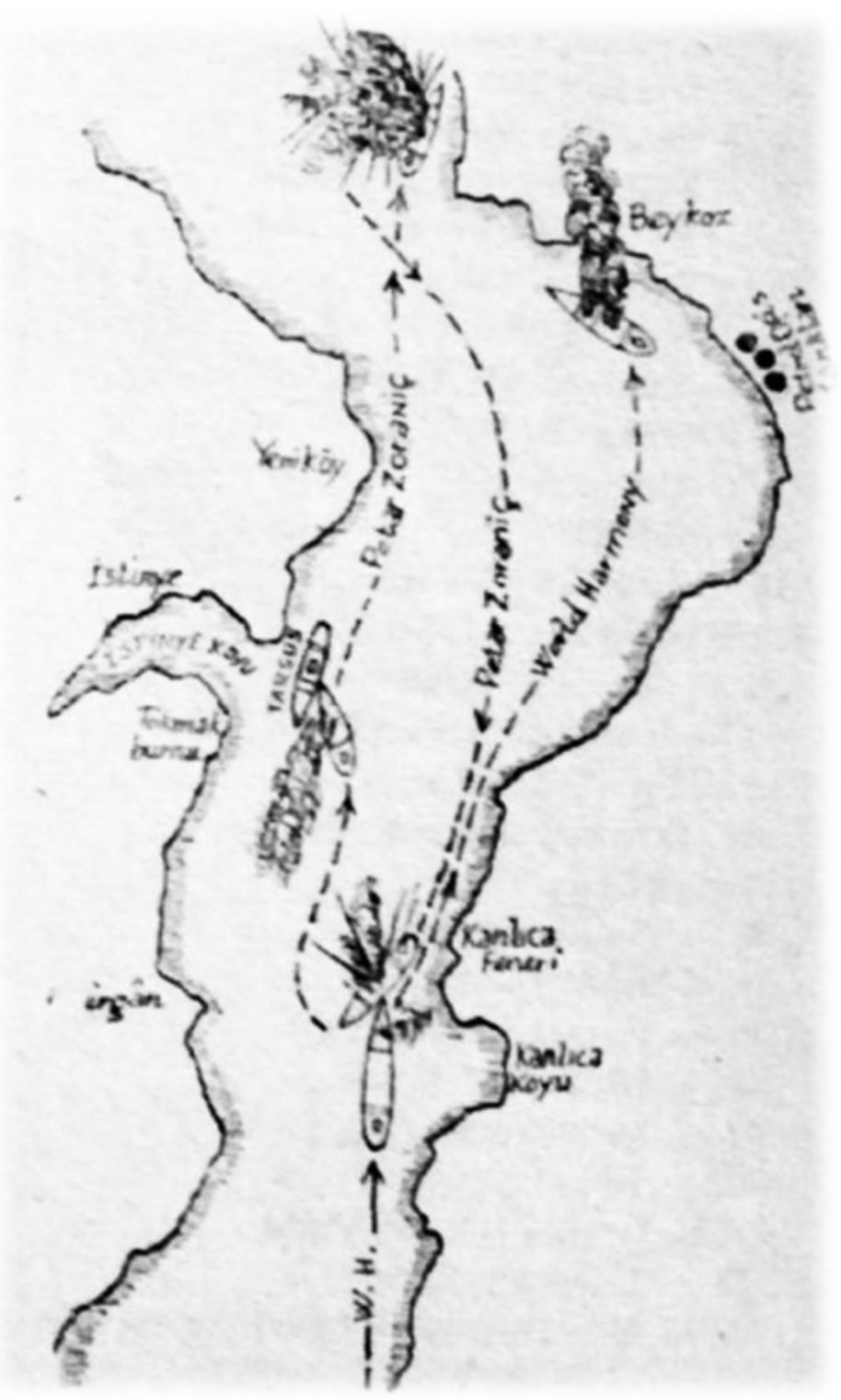

Figure 2.Petar Zoranic- World Harmony accident on an estimated simulative diagram (Koçu,1963)

On the bridge of tanker World Harmony, Master Capt. Aristides Bardzis, was commanding. Captain Aristides Bardzis was born in 1913, in Psara, a small island in the Northern Aegean. After graduated from Syros Technical School, he started to work onboard ships at young age, and, he became a deck officer at the age of 24 . After age 32, he started to work with Niarchos company, owned by Greek shipping tycoon Stavros Niarchos. Captain Bardzis started working onboard of World Harmony in 1957 and first two years, the tanker navigated to and from Persian Gulf to European markets and in 1959 started navigation to Black Sea destinations. So, he had more or less one year experience in the Strait of Istanbul, with a number of passages, about which, the Author is of the opinion that would be insufficient to be familiar with the shape of the Strait. Having passed through the narrowest part of the Strait, the Kandilli area, Capt. Bardzis proceeded further, and he noticed the anchored passenger vessel $\mathrm{S} / \mathrm{S}$ Tarsus off Tokmak Burnu near İstinye Bay, where at that time a large shipyard existed, the İstinye Shipyard. Aligned ship's heading to SW-NE direction with the effect of wind and current, S/S Tarsus was almost headon situation with the World Harmony. And Capt. Bardzis also noticed the south-bound tanker Petar Zoranic, just took the sharpest bend around and proceeding. It was about 02:30 after midnight. Two large tankers moved towards each other. Head-on situation. Pilot onboard Petar Zoranic knew that according to regulation he should be closer to Asian side. So, altered the course more to port. At that time, due to head-on situation and probably in confusion with the Lefthand side navigation rule, Capt. Bardzis was proceeding on the Asian side as well. His vessel was expected to proceed on the European side (port side of the channel), according to the rule, but was proceeding on the Asian side, (Starboard side of the channel). On the opposite side, Peter Zoranic sent out emergency whistle signals but nothing helped, and at the very last moment, to avoid the accident, Peter Zoranic altered "hard to starboard", but it was too late... In about 02:40, bow of the World Harmony crashed into the port bow of "Petar Zoranic" at an angle of approximately 45 degrees in the tank area 2, which contained gasoline. A terrible explosion ensued; gasoline flames covered the front superstructure. Other tanks containing gasoline exploded one after the other due to the force of the impact. There were also explosions on the World Harmony. She had no cargo, but from the previous trip, the tanks were left uncleaned so that an explosion occurred in them. Both tankers were burst into flames; fuel from Petar Zoranic was spilt onto water and caught fire. Although the coast was relatively close, 150 meters away, it was not safe to swim to shore as pouring fuel from Petar Zoranic turned the Strait into a river of fire, with the strong current running towards Tokmak Burnu area. Flames rose tens of meters up, and a fire on the water threatened shores on the coast. Petar Zoranic and World Harmony, after the first crash, left without command and while World Harmony drifted towards İncirköy Banks area near Beykoz and stranded there, Petar Zoranic, with the rudder remained hard to starboard and effect of SW winds, drifted towards Tokmak Burnu area near İstinye, where Turkish passenger ship "S/S Tarsus" was at anchor, a 140meters long luxury passenger vessel prepared for an exclusive cruise to United States. Petar Zoranic drifted towards and allided with $\mathrm{S} / \mathrm{S}$ Tarsus, which prevented her to crash into shore, but, also set the ill-fated passenger vessel in fire. 
Petar Zoranic stayed there allided with S/S Tarsus for 10 minutes, and then, started to re-drift with the effect of wind and current, towards the Beykoz area, to where World Harmony got stranded, and drifted further northwards, and could stop drifting near Selvi Burnu area, which is as far as 2,5 Nautical Miles from the place where the collision took place. Intervention by firefighters and soldiers saved dozens of homes on the coast in Beykoz Bay. In the shallows of Selvi Burnu, shaken by occasional explosions, "Petar Zoranic" continued to be ablaze for the next 55 days. It was ablaze until all fuel on board had been burned, until February 6, 1960. A total of 53 lives were lost in this tragic collision and three ships were destroyed. Capt. Cevdet Çubukçu, pilot onboard Petar Zoranic, lost his life at the very first seconds of accident. Masters of both ships were also amongst the victims. 21 Croatian sailors, 29 Greeks, two Turkish customs officers and a Turkish pilot lost their lives. Two Turkish customs officers' onboard S/S Tarsus. It is the largest maritime accident in Croatian history and one of the greatest tragedies of its kind in the world.

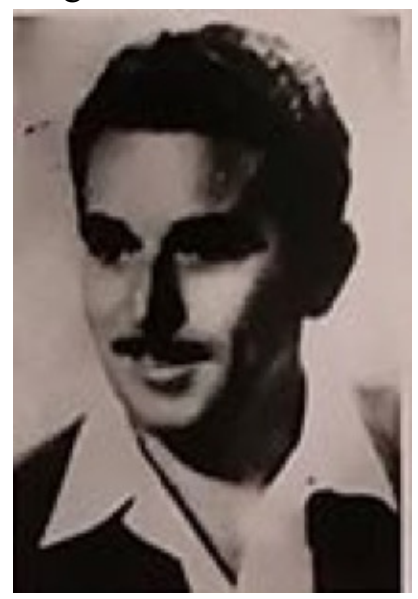

Figure 3. Anton Sablic, Captain of tanker Petar Zoranic

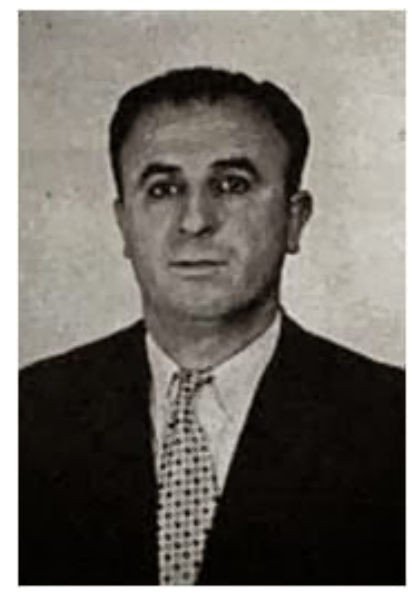

Figure 4. The master aristides Bardzis (Nautical History, 2010)

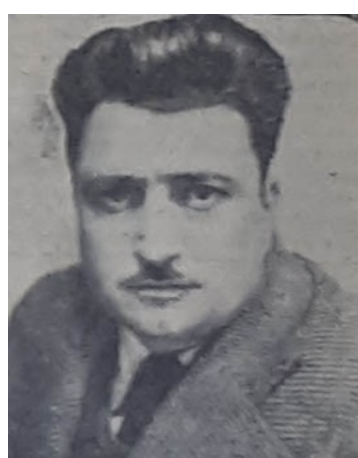

Figure 5. Captain Cevdet Çubukçu, pilot onboard tanker Petar Zoranic

b. After-accident era: The maritime accident was investigated by a fourteen-member commission made up of experts on maritime law and casualties, as well as experts in maritime insurance from Turkey and the former Yugoslavia. In the voting for assessing the responsibilities of ships involved in accident, thirteen members voted for World Harmony to be at fault for 97 percent and the tanker Petar Zoranic only 3 percent. However, one committee member voted that 87 percent were guilty of tanker Zoranic and 13 percent of World Harmony.

After the accident, some safety measures were taken in the Strait. According to daily Cumhuriyet newspaper published on $20 / 11 / 2019$, these measures were:

1. Night-time passage of laden or ballast tankers of all sizes and ships carrying dangerous cargo prohibited,

2. Speed limit was set to 10 Knots as maximum,

3. Distance between passing ships wea set to 1000 yards as minimum (914 meters)

However, these measures mentioned in the newspaper were not enforced by law and not known if applied at all, even if they did, not for long and were not remained as permanent, faded away as the time went by after the accident.

c. Accident analysis: In the light of information above; and according to a number of criteria, the following conclusions were made:

$>$ Navigational Errors: While Yugoslavian tanker Petar Zoranic followed the appropriate course in compliance with Istanbul Port Regulation, as set forward at Figure 3, the Greek tanker, World Harmony was on the right-hand side of the channel, which meant she followed the wrong course, not in compliance with above-mentioned Regulation, which was in force at that time. Compliance: Petar Zoranic. 
$>$ Pilot onboard: Having a local pilot onboard, the Yugoslavian tanker, M/T Petar Zoranic had fulfilled the necessary initial requirements for a safe passage. Compliance: Petar Zoranic.

$>$ Meteorological/morphological difficulties: As another factor, Southbound M/T Petar Zoranic was proceeding against the wind and current, at the time of accident strong SW winds and northerly current were prevailing, as local people call it, the "orkoz". That possibly made the navigation more difficult for both vessels, especially for the northbound one.

$>$ Speed in the strait: Another issue was the speed of both vessels. According to estimation, Southbound and laden Petar Zoranic was not exceeding 10 knots over the ground, as she proceeded against the wind and current. But, the speed of World Harmony could be around 15 knots-and even more. Petar Zoranic has the points here.

$>$ Left-hand side navigation and crossing areas: The most controversial issue with regard to this accident is the "left hand navigation" that was in effect in the Strait of Istanbul during that time. It was a long-established rule, however, effective since 1933, but as the right-hand navigation was -also- partly used in the Strait, it can be claimed that this two different and in fact, opposite passage system led the captain of World Harmony into confusion. Two vessels in reciprocal courses used different rules: World Harmony complied with the international rule (Rule 14 of the collision regulations) which ordered to alter the course to starboard in head-on situations while the Petar Zoranic complied with the local rule (Article 26 of the Istanbul Port Regulation) which ordered to follow the Port-hand side of the channel (That included, by the essence, to alter the course to port for vessels in reciprocal courses). But, however, this was no excuse for the Captain of World Harmony. The long-established customary rules in the maritime transportation ordered the captain to be "prudent and completed". That meant for the Captain of World Harmony to have the proper local knowledge including the local rules or to have a local pilot picked up at the Southern entrance of the Strait.

\section{M/T Lutsk-M/V Cransky Oktiabr Collision}

a. Accident: Strait of Istanbul saw one of the most terrific accidents on 1st of March, 1966, in which two ships, one being a bulk carrier the other a tanker, of Black Sea Shipping Company, largest shipping company of the world during that time, collided. Black Sea Shipping Company was a Ukrainian shipping company based in Odessa. During Soviet rule, the company held the title of world's largest shipping company for several years and was instrumental in important foreign trade and international aid initiatives of the Soviet government. As a result of strong political and economic relationship and collaboration between Soviet Union and Cuba (Remember October 1962 Cuba Missile Crisis) at that time, Kransky Oktiyabr had her cargo loaded from the port of Puerto Padre of Cuba, 15.500 tons of sugar in bags. On Friday, March 1, in the afternoon, Kransky Oktiyabr passed through the Strait of Çanakkale and by night, approached the Strait of Istanbul. Loran Antonovich Kozyr, Captain of Kransky Oktiyabr, felt confident on the commanding bridge, when the Chief Officer asked if he required a pilot for passage, he answered twice: "No, let's go without a pilot". The moon was shining, a clean night, visibility was good, and state of sea was calm. At 22.07, they passed the lighthouse of Ahırkap1 and at 22.15, they started turning to the Starboard at $048^{\circ}$ around the Kizkulesi lighthouse. Ahead was the most responsible section - the line of transition to Left-hand side traffic and the road close to European side in front of Dolmabahçe Palace extending to Ortaköy area, on which ships often stayed on anchor, whose had weak anchor lights which were poorly visible at night.

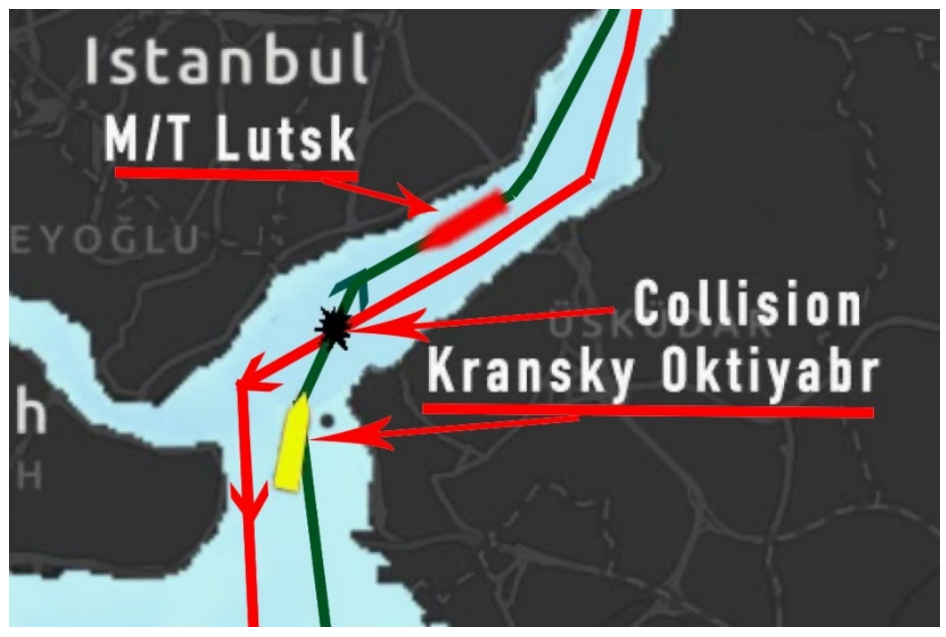

Figure 6. Positions 4 minutes before and place of collision of Lutsk and Kransky Oktiyabr 
Suddenly, it was at 22.18, the third officer standing at the radar reported: "I see a large vessel on the screen of the radar". It was, 1.5 Nautical Miles ahead, red port side light and two white mast lights were visible. This was the tanker "Lutsk". She was proceeding to South-West, in front of Ortaköy area, closer to the European coast- Starboard side of the Strait, on a wrong course. According to the rules of Left-hand side navigation in the Strait of Istanbul, as set out in Figure 3, she was expected to be closer to the Asian coast, not to the European coast. Captain Kozyr ordered the engine to slow down, "Dead Slow Ahead!". On the opposite side, under the command of Captain Vladimir Tolochko, the tanker Lutsk was laden with 32.000 Tons of Crude Oil. Captain Kozyr, on the bridge of Kranskiy Oktiyabr, saw Lutsk on the port side of his vessel, and knowing her being on the wrong course, he decided to pass "red to red" (Port-to-Port). But at the very moment, he saw the Lutsk altering her course to port. He wanted to do the same, and ordered "hard to port". But, the Kransky Oktiyabr, being at the slowest speed, did not answer to the command. Then Captain Kozyr ordered "Hard to Starboard" accompanied by one short signal with the whistle. In response, he heard two short signals from the Lutsk. That meant bad news, she was insisting to alter her course to Port! Rules were rules, it was obvious that Captain Tolochko wanted to go back to the correct course ordered by the Port Regulations. At this point, Captain Kozyr, altered his mind again. "Engine half ahead, rudder hard to port" he ordered, and gave two short signals declaring this decision. Onboard the Tanker Lutsk, Captain Tolochko interpreted these maneuverings of Kransky Oktiyabr as if they were done to avoid collision with a ferry crossing from Asian side to European side (There was such one indeed, Capt. Tolochko had said about this interpretation of him to Captain Kozyr after the accident). But the vessels were very close now, only a few cables. The distance between the vessels was about two miles when they first saw each other, and now, it was less than a mile. Captain Kozyr noticed that it would not be possible to avoid collision with rudder and engine commands. The best way was to stop the movement of the ship. Then he ordered "Full astern and let go the starboard anchor". At 22.22, tanker Lutsk crashed onto Kransky Oktiyabr. Contact point was on the starboard side, just ahead of the accommodation of the Lutsk and on the stem of the Kransky Oktiyabr. The stem of Kransky Oktiyabr punctured a hole on the shell of the tanker about 5 meters in diameter through which crude oil started to spill immediately. With the effect of the collision, similar to the push of a tugboat, tanker Lutsk pushed and turned the bow of
Kransky Oktiyabr towards her starboard side and both vessels now turned to the Sea of Marmara and proceeded further, with Lutsk continuously leaking crude oil. Some 750 tons of crude oil was spilt to the sea until both vessels arrived to Sea of Marmara, where two ships were separated from each other and Tanker Lutsk proceeded further South in order to flush the remaining of the punctured tank and Kransky Oktiyabr proceeded to the Ahırkap1 Anchorage. It was nothing but only a luck that the crude oil did not catch fire during the crash and the tank did not explode, most probably the fullness of the tank prevented gas accumulation over the surface which if not, could cause a fire.

But, this did not mean that the crude oil that was spilt would never catch fire. In fact, that happened after one and a half hours from the accident, at Karaköy district, where local ferries from and to Kadıköy area were coming alongside on a pantoon connected ashore (See figure 12). One of these local ferries, named Kadıköy, built in 1912 in France and 54 years old at that time, was moored to the pantoon at the time of accident, and would leave for Kadiköy (district) at 23:45, but due to an intense smell of crude oil in the air, the ferry which already embarked the passengers, was kept waiting. It was around midnight, due to unknown reason, perhaps, according to some eyewitnesses due to an overthrown aflame piece of paper from the front section of the ferry, caused a spreading fire over the sea surface. The passengers of the ferry, which were around 1500, abandoned the ferry immediately. The Ferry was on fire and fire broke the shore connections -ropes- and set the ferry adrift without being under command. Ferry drifted towards Sirkeci area after which rescue vessels belonging to Turkish Naval Forces Command took her under control.

The ferry "Kadıköy" was totally destroyed by the fire. The fire spreaded over the sea further and the front section of Italian-flagged cargo/passenger vessel San Georgio, which was alongside at Karaköy berth a few hundred meters away, also caught fire. The ship was unmoored and moved to anchorage. The other ships at the nearby berths, Turkish cargo/passenger vessels M/V Sus and M/V Ege were also taken to anchorage as a precaution. Galata bridge was also suffered from fire, the shops under the bridge were damaged from fire. Across the pantoon, all the seafront window glasses of Rihtım Branch of Ziraat Banks were melted. This was the second incident at which oil and derivatives caught fire on the water surface of the Strait of Istanbul after an accident. The first one was Petar Zoranic-World Harmony accident. 


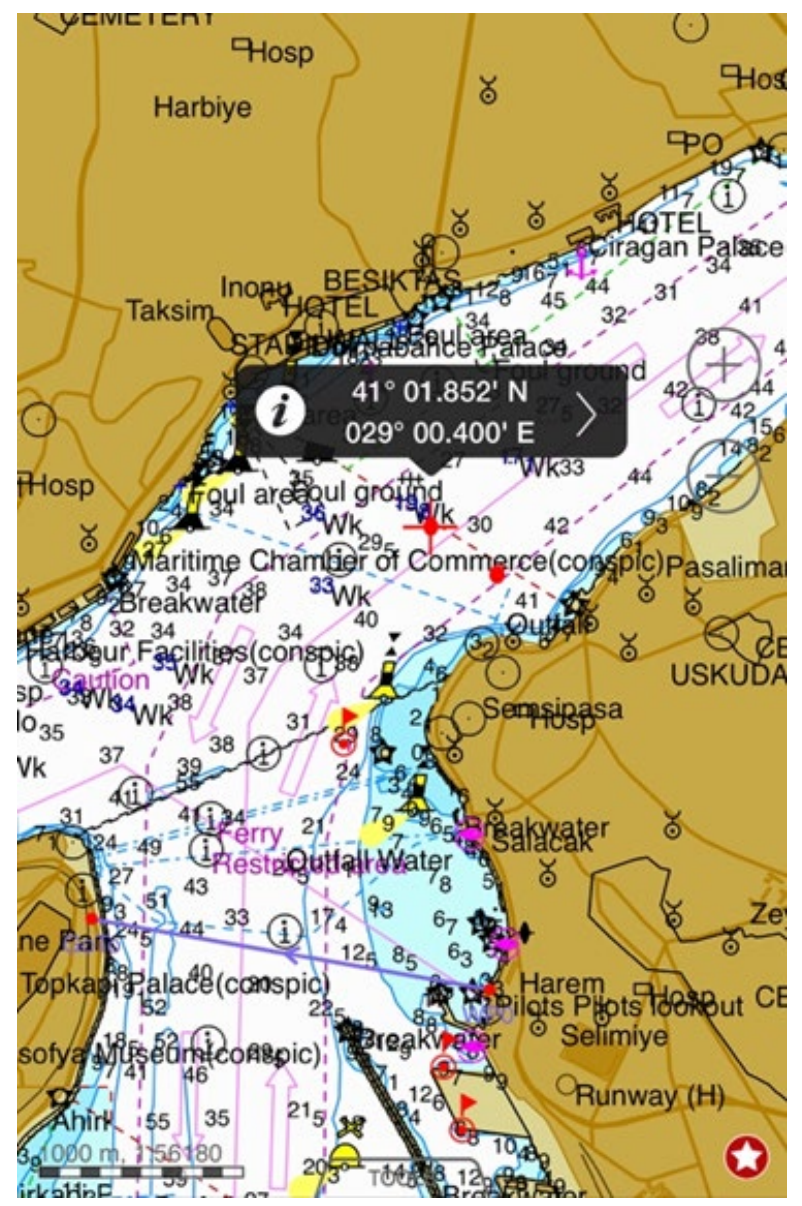

Figure 7. Exact position of the Lutsk-Kranskiy Oktiyabr accident. Position fixed by the officers on the bridge of Kranskiy Oktiyabr: $4101.85 \mathrm{~N}$ and $02900.40 \mathrm{E}$

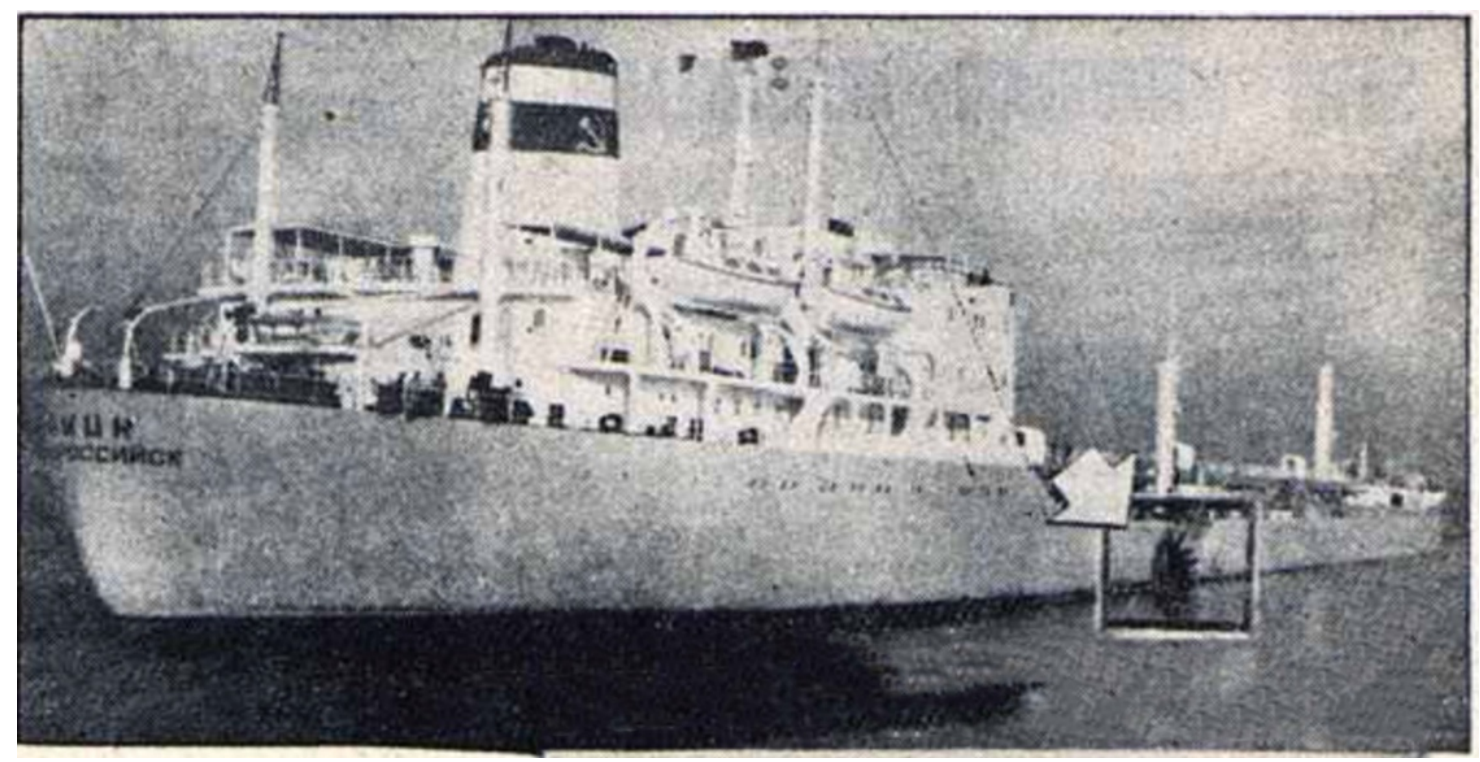

Figure 8. This photo, Property of Özdemir Gürsoy and published on Daily Milliyet Newspaper on 03.03.1966, shows the damage on the starboard side of tanker Lutsk. 


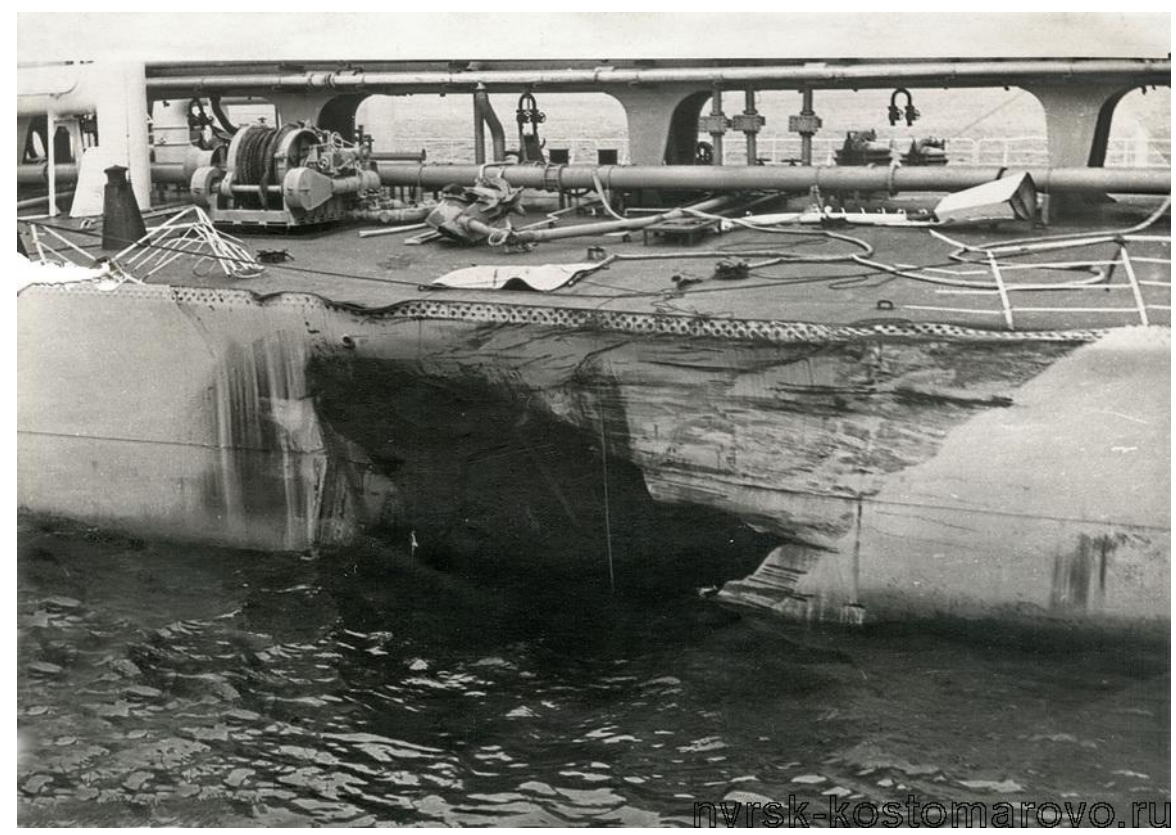

Figure 9. The damage on the single-hull Lutsk shows the gravity of possible disaster which was very near to happen.

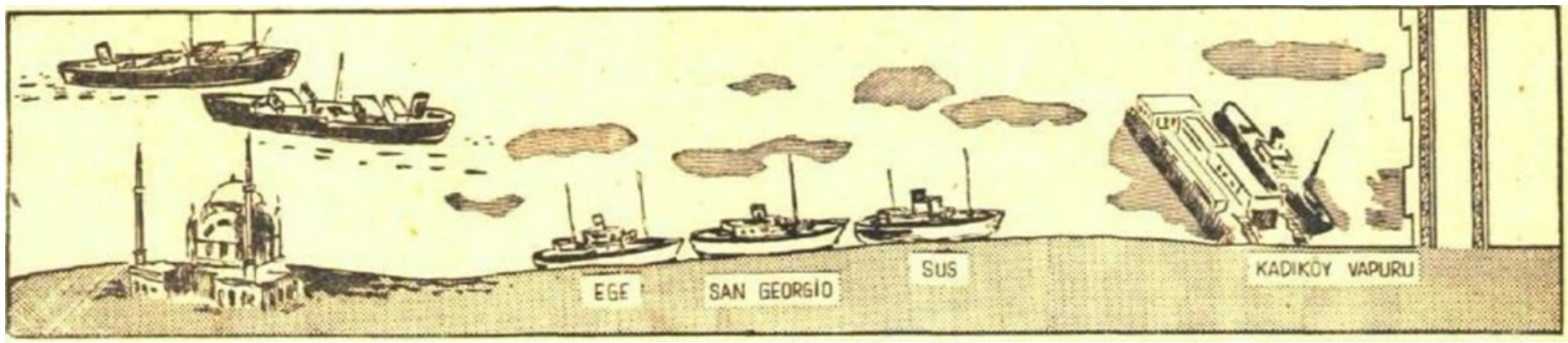

Figure 10. The illustration of the Lutsk-Kransky Oktiyabr accident published on daily newspaper Cumhuriyet on 03/03/2019

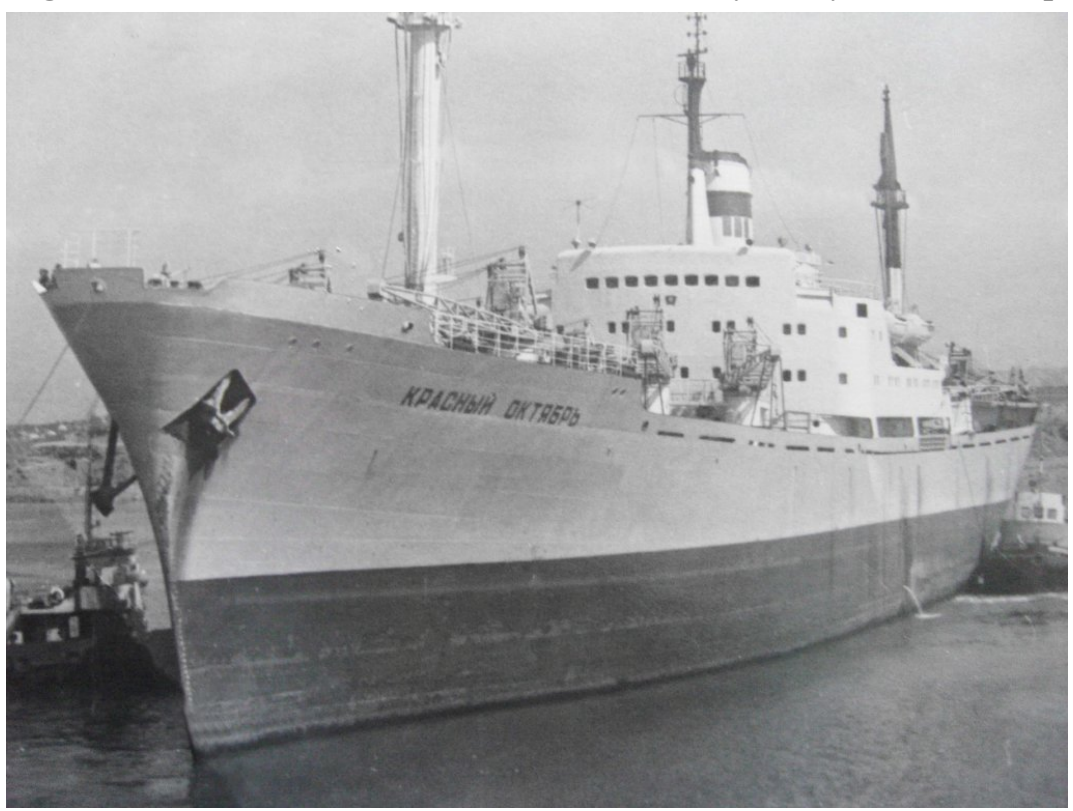

Figure 11. The dry cargo vessel Kransky Oktiyabr 
Table 3. M/V Kransky Oktiyabr/Mt Lutsk ship characteristics

\begin{tabular}{|l|l|l|}
\hline & $\begin{array}{l}\text { M/V Kransky Oktiyabr } \\
\text { (North-Bound) }\end{array}$ & $\begin{array}{l}\text { M/T Lutsk } \\
\text { (South-Bound) }\end{array}$ \\
\hline Date-Place Built & $23 / 05 / 1963-$ Soviet Union (Kherson Shipyard) & $\begin{array}{l}08 / 05 / 1964-\text { Ishikawajima Harima Shipyard, } \\
\text { Aioi (Japan) No.619 }\end{array}$ \\
\hline Owner & Black Sea Shipping Company & Black Sea Shipping Company \\
\hline Type \& Flag & General Cargo-Soviet Union & Tanker-Soviet Union \\
\hline Pilot Onboard & NO & NO \\
\hline Cargo & $\begin{array}{l}\text { Fully Laden Sugar in bags-15.500 tons (From } \\
\text { Cuba) }\end{array}$ & Fully laden- Crude Oil 35.000 tons \\
\hline Dimensions (Lxbxd) & $169.91 \times 21.85 \times 12.9 \mathrm{~m}$ & $207.04 \times 27.06 \times 11.08 \mathrm{~m}$ \\
\hline Tonnage & 11206 GT & 23110 GT \\
\hline Max.Speed & 18.2 Knots & 16.5 Knots \\
\hline Engine\&Propeller & Steam Turbine, Single Screw & Steam Turbine, Single Screw \\
\hline
\end{tabular}

b. After- accident era: The Prosecutor's Office opened proceedings against the captains of Russian ships under Article 383 of the Turkish Penal Code. This article (1n that time) contained the following provision: "A person shall be sentenced to 30 months' imprisonment and a fine of up to 100 pounds if he or she causes a fire or explosion or destruction of the public hazard due to precariousness and carelessness or inexperience in art, inexperience in the profession, or in breach of rules or regulations." Both vessels were taken under arrest. Soviet representatives of the Black Sea Shipping Company accepted the guarantee payment. The Kransky Oktiyabr was released first, and after the payment of 29 Million 675 Thousand Turkish Liras as guarantee, the tanker Lutsk was released on 1 May 1966 and the ship left Istanbul for Odessa on that day.

d. Accident analysis: The following are the findings with regard to this accident (Applying the same criteria):

1. Navigational errors: The Kranskiy Oktiyabr followed the appropriate course in compliance with the Istanbul Port Regulation. The other vessel involved in the collision; the tanker Lutsk did not follow the appropriate course in the same regard. After the first sight, both vessels came to a head-on situation when Lutsk altered her course to port and Kransky Oktiyabr altered her course to starboard. In this situation, both vessels seem to be confused between the rule imposed by Port Regulation and the one imposed by Collision Regulations on head-on situations. In fact, Rule 18 of the 1960 version of International Regulations for Preventing Collision (Revised in 1972) which came in to force in 1965, ordered that "When two vessels approached each oth- er from reciprocal or nearly reciprocal courses so as to involve risk of collision, each shall alter her course to starboard" (Same rule was derived into 1972 COLREG's as Rule 14) (Lameijer et al, 2004). To comply with the Collision Regulations; each vessel should alter her course to starboard; Kransky Oktiyabr did this but Tanker Lutsk did not. On the other hand, to comply with the İstanbul Port Regulation Article 26, both vessels should alter their courses to port, from this perspective, Lutsk complied with the regulations and Kransky Oktiyabr did not. It is apparent that there was a conflict between two regulations as detailed above. This confusion might have played a critical role in the Lutsk-Kransky Oktiyabr accident.

2. Pilot onboard: Both vessels, neither Kransky Oktiyabr nor Lutsk, did not use pilot for their passage through the Strait of Istanbul.

3. Meteorological/morphological difficulties: There was not any noteworthy conditions with regard to current or visibility. Visibility was good and currents were weak.

4. Speed in the strait: Speed of both vessels might have played a role in the accident from the perspective of preventing it, but this was marginal. Kransky Oktiyabr reduced her speed, which negatively affected her maneuverability, but on the other hand, this action reduced the impact of the collision. On the other hand, Lutsk did not reduce her speed, if she did, the collision could have been avoided.

5. Left-hand side navigation and crossing areas: After the accident, Captain Tolochko and Captain Kozyr sent telegrams to their main offices, in other 
words, to Black Sea Shipping Company. In their telegrams, the captains blamed each other for being responsible of the accident. However, Minister of the Navy, V. G. Bakaev, had a different viewpoint. According to him, none of the captains was responsible of the accident. Responsible was the rule, which required a crossing from Left-hand side navigation to right-hand navigation near exit. This view, however, has a truth in it. In a narrow Strait, crossing of the lanes apparently increases the risks and leads to confusion. Remembering that at 1966 there was no shore-based assistance providing information to ships about the opposite traffic and their intention, this crossing area played a decisive role in the collision between Kransky Oktiyabr and the Lutsk. As it was detailed in the navigational errors section above, left hand navigation and crossing areas might have confused both captains with the conflicting Collision Regulations rule regarding the head-on situations.

\section{M/T Independenta-M/V Evriali Collision}

One of the world's largest marine accidents occurred on November 15, 1979 in the Southern approach of the Strait of Istanbul. Romanian flagged tanker, $\mathrm{M} / \mathrm{T}$ Independenta, which had a capacity of 147.631 DWT, was a new-built vessel with only two and a half years of age. Nicolae Ceausescu wanted, in the 1970s, to become independent from Russia, in terms of oil. Impressive-sized vessels had begun to be built. This is how "Independenta", the largest ship ever built in Romania came out, the "admiral" of the commercial fleet, a mioritic "Titanic", the first "child" from a list of high tonnage vessels, with swimming pool, hall of games and built 700 kilometers of welding, 150 kilometers of cables, 100 kilometers of pipes are just some of the data of the mastodon project. The M/T Independenta was a 283 Meters in length, 46 meters in breadth supertanker with 22meters of moulded depth, excluding the superstructure. She was launched in May 27, 1977 on a ceremony in which Elena Ceausescu, wife of Romania's President Nicolae Ceaușescu's wife, did not succeed in breaking the champagne bottle against the ship's hull, which accepted a sign of bad luck for the vessel.

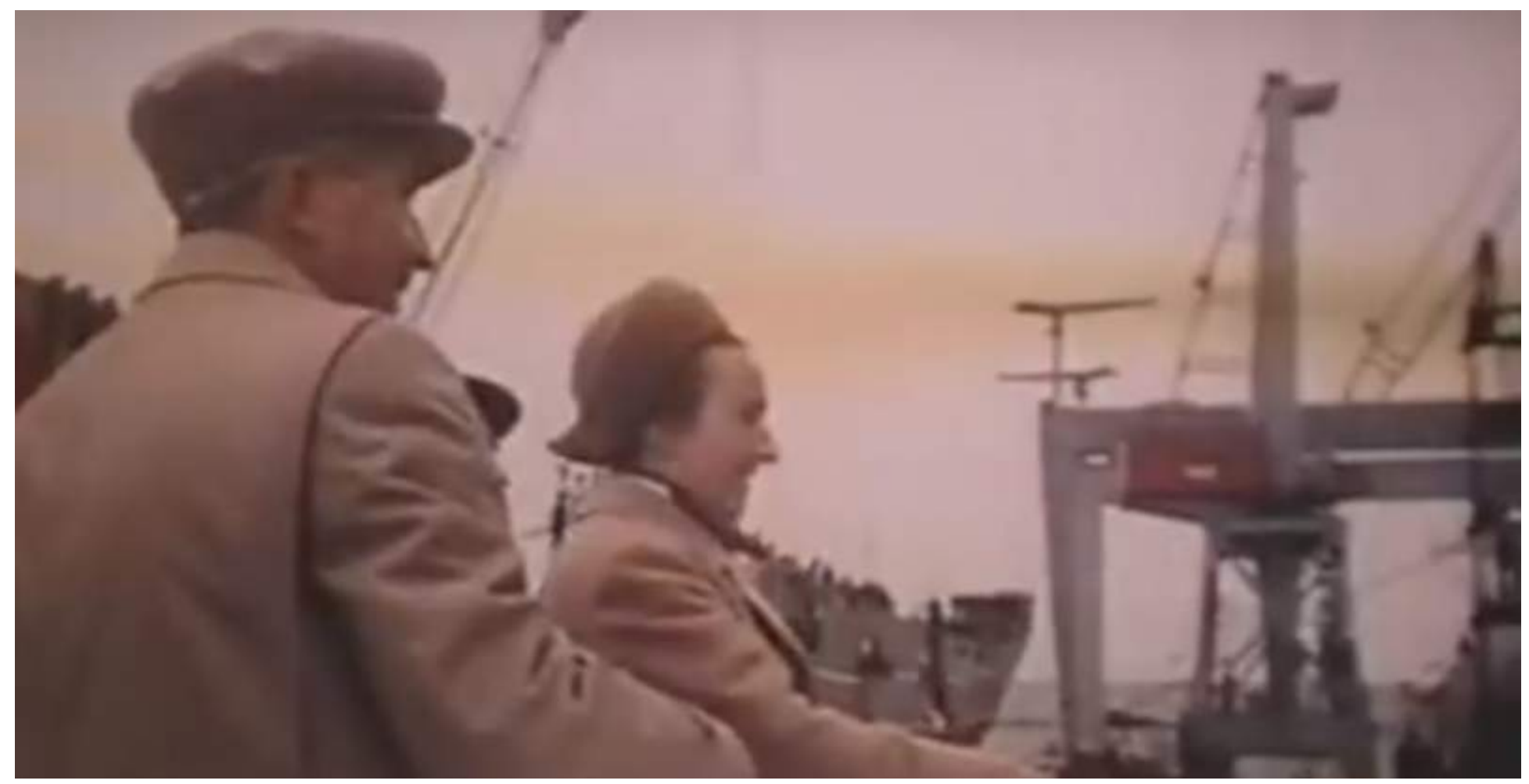

Figure 12. Elena Ceausescu trying to break the champagne bottle, a bad sign for the ship's fate 
On her last voyage, which was terminated by a tragic accident, Independenta was on the way from Libya to Constanta, with a cargo of 93800 tons of Es-Sider crude oil. The vessel also had 260 tons of heavy fuel oil bunkers on-board. $\mathrm{M} / \mathrm{T}$ Independenta was not fully loaded (Her tanks were $2 / 3$ loaded, as the full capacity was 147.631 tons; this incomplete load of crude-oil in the tanks probably caused gas accumulation in the tanks which played a role in the accident). $\mathrm{M} / \mathrm{T}$ Independenta was under command of Captain Dorinel Grigore Mihai, born on 01 May 1944 in Candesti, Buzau in Romania, 35 years old at the time of accident. In fact, Captain Constantin Preda was the usual Captain of the tanker, who was onboard during the all previous voyages, then left on holiday; Captain Dorinel Mihai replaced him for the last voyage. Being a captain onboard, an oil tanker was not Captain Mihai's best choice, and he had already resigned on $2^{\text {nd }}$ of November and his resignation would take effect after 15 days, on the $17^{\text {th }}$ of November. According to his crew, Capt. Mihai was an enthusiastic person, as a hobby, he often played violin and "ballad" by Ciprian Porumbescu, the famous Romanian composer, was his favorite (Mihailescu, 2009). But that did not mean that he was not a prudent seaman. He was diligent to comply with safety rules and recommendations. He required a pilot on his arrival at the entrance of Strait of Istanbul. In fact, Independenta arrived in Istanbul anchorage on 14 November at 16:00, but as nighttime passage was not permitted for large tankers of this size, the tanker went to anchorage to wait until the early morning on the next day. Time to enter was given at 07:00 Local Time on 15 November 1979, a rendez- vous to which Capt. Mihaiarrived two hours earlier, at 05:00 local time. He was recommended to slow down and wait for the pilot near the entrance. At that time, there was no land-based traffic management system established in the Strait of Istanbul, traffic management was partly carried out by the pilot stations and pilots themselves. The pilot station at service for Strait of Istanbul then was located at Harem district, which was relocated to More-Southerly İnciburnu area about 20 years later, due to its location being too much inside of the Strait, which had used to deteriorate service availability to vessels require pilot in relevant pilot boarding area. On 15 November 1979, in Istanbul, early morning, state of the sea was calm, but visibility was restricted, around 1.5 nautical miles. The sunrise time on that day was $06: 51$, according to (-2) GMT calculation, for this reason, entrance time of tanker Independenta was fixed at 07:00. At the other end of the Strait, another ship, Greek freighter Evriali entered the Strait at 04:00 and picked up the pilot near Kavak Point. The pilot's name was Capt. Dinçer Sümerkan. Under the pilotage of Capt. Sümerkan, freighter Evriali safely passed through the Strait arrived near K1zkulesi, around which Capt. Sümerkan left the ship; time was $05: 15$, just twenty minutes before the collision. This was the common practice at that time, leaving the vessels right after the Kizkulesi area, so what Capt. Sümerkan did was not something exceptional, but there was one issue which was noteworthy, if not exceptional, that was a large tanker approaching and visibility was not so good. Capt. Sümerkan explained the whole situation on a TV Interview conducted by Romanian Digi 24 TV in 2017 as follows: "It was very dark, there was fog, the visibility was about 1,5 nautical miles. Independenta was 4 nautical miles from us at the last radio talk. In the morning around 4 o'clock, I had boarded the Evriali ship, at 5:15 I disembarked and headed for pilot station at Harem, and at 5:35 I heard that Evriali collided with the Romanian ship. As far as I learned, instead of heading to course of 260 to the starboard, she altered about 30 degrees more to port from existing course, to 160 , to the port side. But I don't understand why he did that". At 5.15 Capt. Dinçer Sümerkan, pilot of M/V Evriali, left the vessel after a beam of Kizkulesi and according to him, he left the ship heading to 190 degrees, which is the usual course after passing K1zkulesi until which the course should be 235 degrees. If Evriali had continued on this course, the collision would not have occurred. Evriali came to a head-on situation with the tanker, and altered her course to port, directly towards the tanker. On the reciprocal course, the Tanker altered her course to Starboard. On Evriali, Captain Alekos Adamopoulos was 29 years old. According to daily newspaper Cumhuriyet, on 19 November 1979 issue, it was claimed that both captains had a conversation on VHF minutes before the accident. According to the news, on this conversation, Captain Mihai, warned Captain Adamopoulos to pass "port-to-port" and this request was approved by the Greek freighter. However, in order to comply with this agreement, Captain Adamopoulos should alter the Freighter's course to starboard, which he did the contrary. Altered to port. Reason for this, according to newspaper, could be a misunderstanding between two captains. Captain Adamopoulos could have understood the proposal to pass "Port-to-Port" as, "hard to port!" and give this command to the helmsman. On the Independenta, some seafarers were on deck, with the camera, because the Strait and the city of Istanbul were wonderful. But there was something going wrong, in the twilight, a freighter was very close, a few hundred meters. Independenta insistently altered to starboard, Evriyali insistently altered to port, almost in vertical course, as they got closer. It was 05.33, right before the collision, Captain Dorinel Mihai give five short signals with the whistle, which was heard all seafront houses in Kadıköy and Kabataş (Özözlü, 2018). Two minutes after 
Evriyali's stem, close to the starboard bow, crashed into Independenta on the port side, on No. 3- No. 4 tanks area, just in front of the accommodation. Especially No.4 tanks were critical area because these tanks did not contain crude oil, but gasoline. Soon after the crash, crude oil started to pour out from the tanks and sparks due to metal-to-metal friction, pouring crude oil-or gas- caught fire, and afterwards, there was a huge explosion, due to which, all the windows glasses in a $6 \mathrm{~km}$ diameter in Istanbul city were broken. Abandon ship bells rang on board Independenta. Chief Engineer of M/T Independenta, Sorin Mihăilescu, described the tragic moments as follows (Cumpana, 2006): "I went on the bridge. The first who saw the Evriali ship was Commander Mihai Dorinel. He was focused and seemed a little anxious. I also saw the ship heading in the opposite direction towards us. At one point, the commander noticed the wrong direction. The foreign ship did not sail "on the starboard side" to show us her port side, as was the rule. We all thought he was a little off the road and that he would soon correct his course. Our commander put his handset on the radio and sent them to come «port to port», that is to pass parallel with us and to see the red light from his port side, as he saw the one from our port. It is an elementary rule of sea navigation at night. No one answered. Later, I learned that the ship, though passing through the Strait, had no pilot on board, the commander was not in command, and permanence was ensured only by the ordinary cart, an officer, a helmsman and a sailor. I never understood what was their intention. Maybe they bet on the routine, maybe they didn't even see us, maybe they were disconnected because they were just getting out of trouble, maybe they were worried about something else. There were some rours that they had women on board or that they were doing "business" with the locals who were fishing in the area. Mihai Dorinel kept calling him over the radio. The other ship was silent. It was now 5.20. The foreign vessel continued to proceed towards us. We were beginning to distinguish their profile and dimensions. It was a cargo of about 5,000 DWT. Later I found out that it was called "Evriali", it was private property, under the Greek flag and carrying steel product. Within minutes, our commander's calls began to become more and more agitated. I was worried about his voice. At that moment, the whistle of our ship came into operation; their thick and frightening scream was a desperate attempt to warn the stranger of our presence and imminent danger. But the ship in front of us gave no sign, instead, it changed course and turned perpendicular to ours. Due to the size and weight of the "Independence" tanker, any avoidance manoeuvres were impossible. The "Evriali" had come close enough to see its light from the starboard, and not from the port as normal. There was nothing left to do. It was now 5.30. From a defense instinct, I pulled out the flashlight and tried to signal. The killer ship continued on its way and came directly toward us, almost perpendicular. It was now 5.35. «Independenta» received the blow in the port, near tanks 3 and 4 . There was a deafening thud and a loud metallic noise. A roar of torn and crushed iron mixed with the desperate screams of the people. The shock of the collision was not felt. Independenta was 150,000 tons, it was huge, and the Greek one about 7,000. There was no explosion at the time of the impact, but due to the metal-to-metal friction, there were strong sparks, which ignited the oil stream that had started to pour through the crack produced by the blow. Then the first explosion took place. A frightening thunder swept toward the vault of the sky and then crashed upon us, bursting with its shock wave. A huge column of apocalyptic red, yellow and orange flames tore through the night's shattering darkness. Magnificent black and smoky hummingbirds, lit by flames, camped over us and the ship. There are no real grounds for rumours and speculations regarding the inert gas system that it was defective, that it did not work. I affirm with all responsibility that this system worked. The fire broke out because of the sparks that occurred at the time of the collision. Then remember that tank no. 4, although it did not contain oil, it had gas."

The explosions after the accident were so huge that the glasses on the windows of the Kadıköy district and the glasses of the Topkap1 Palace were broken, although the entrance took place quite a distance. In Istanbul only, 10 million Turkish Lira (about $\$ 250$ thousand) had to be spent for the repair of the windows. Oil spilt from the tanker spread over the sea in an area of 1.5 miles and burnt, occasional explosions occurred in the tanker, the people of Istanbul experienced a hell of fear. A dark smoke spread all over the city. M/T Independenta, which was $3 \mathrm{~km}$ away from the Topkap1 Palace at the collision, drifted closer to the city out of command towards the shores of Kadiköy, on the other hand, the oil continued to be burned and the ship was bursting. Drifted up to four hundred meters before the Haydarpaşa breakwater, the tanker was stranded there and then split in two accompanied with a big explosion. The flames from the exploding tanks were rising up to 50 meters in the sky, and the thick, toxic and smoke fumes collapsed like blankets over the city. 


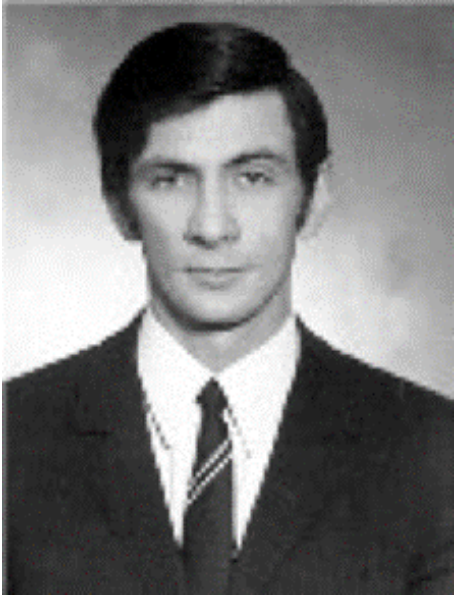

Figure 13. Captain Dorinel Grigore Mihai, the unfortunate captain of the Independenta tanker, was among the 11 unfortunate sailors whose body was not found after the accident (Cumpana, 2006).

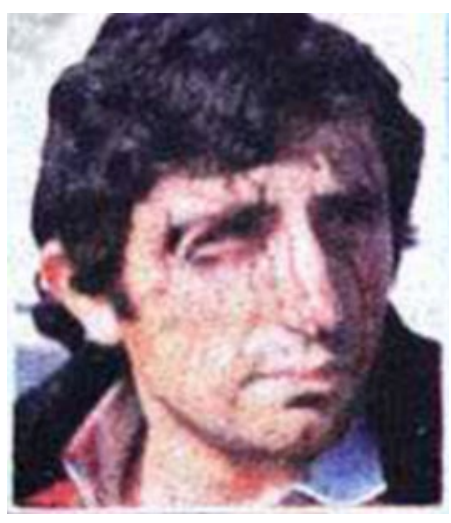

Figure 14. Capt. Alex Adamopoulos, Captain of the Greek freighter Evriali (Photo from Turkish Daily Newspaper Milliyet, Published on 16.11.1979).

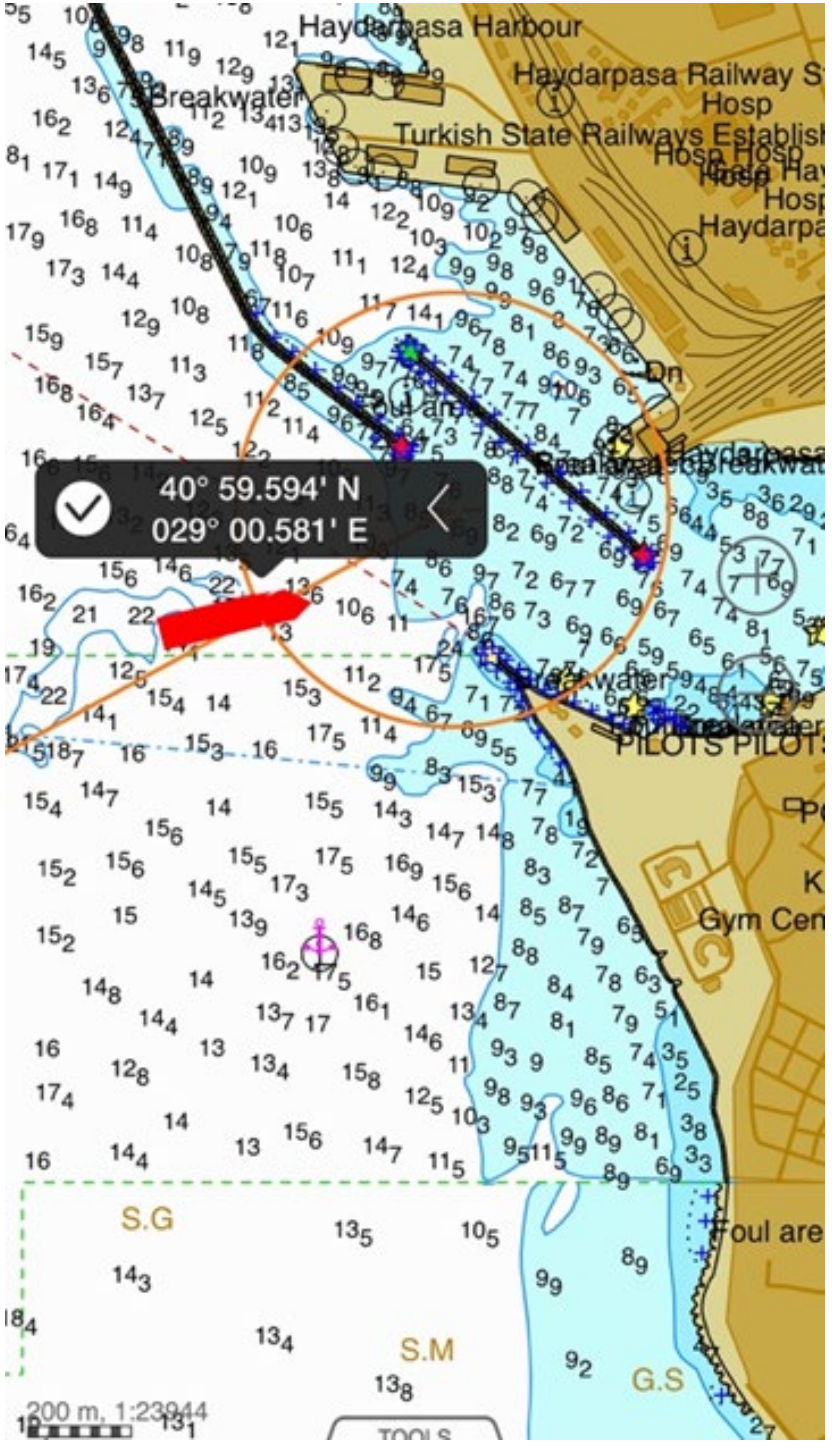

Figure 15. The location where Independenta went aground 


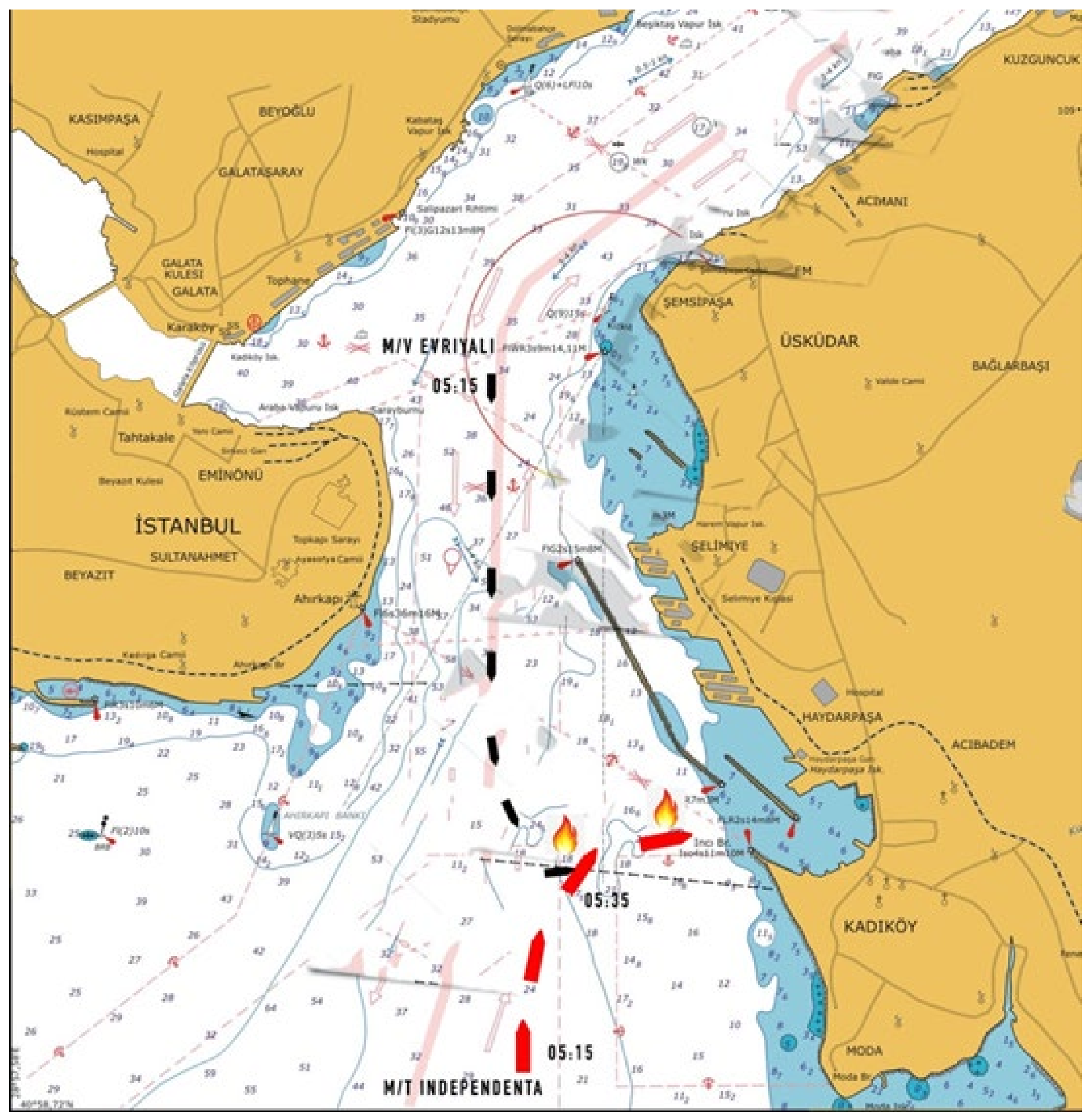

Figure 16. Estimated collision tracks and site of collision of $M / V$ Evriyali and $M / T$ Independenta 


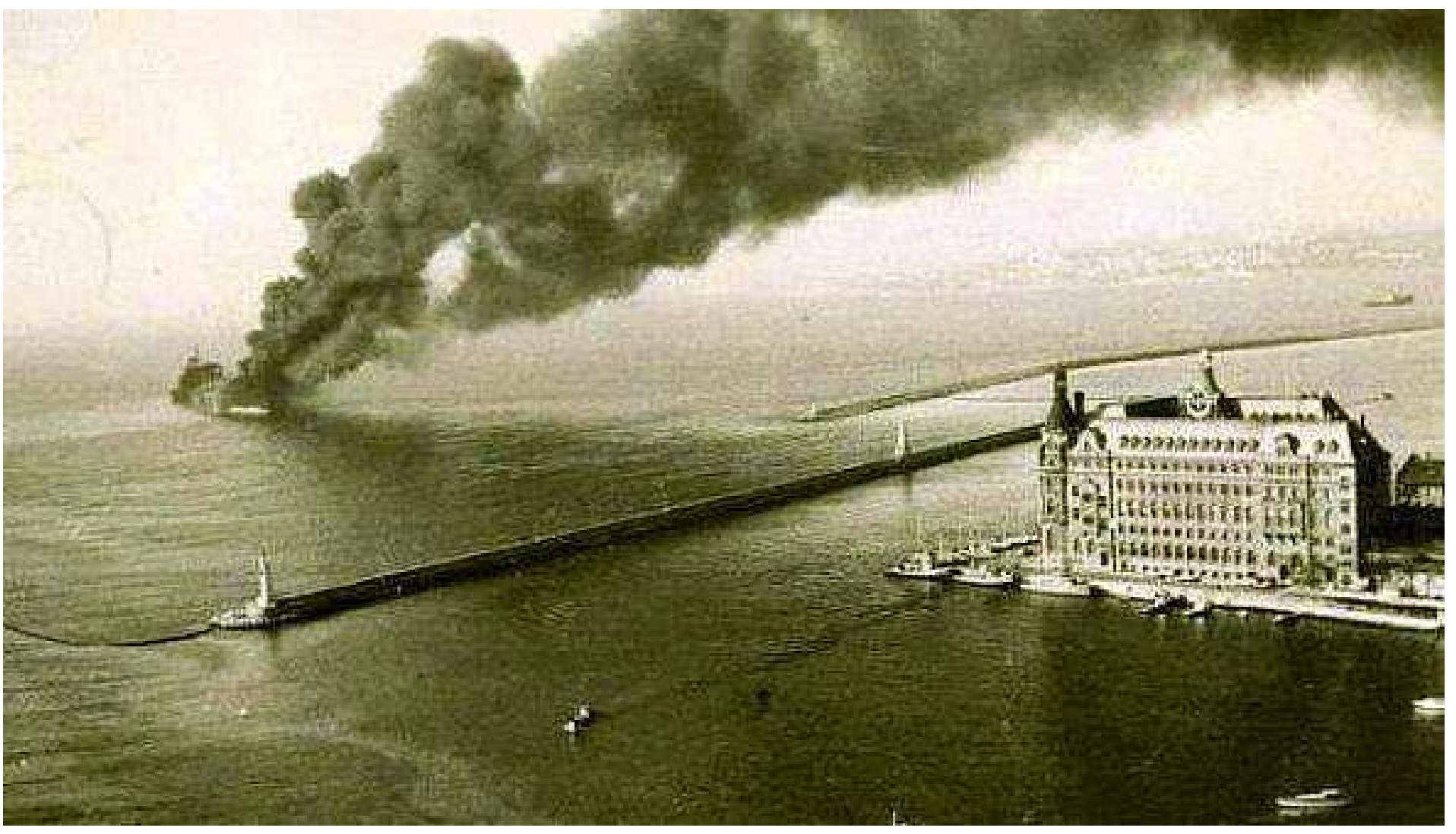

Figure 17. Independenta aground and on fire right before the Haydarpaşa breakwater. Source: https://onedio.com/haber/11maddede-bogaz-daki-en-buyuk-tanker-faciasi-independenta-515265

Table 4. Mt Independenta/Mv Evriali ship characteristics

\begin{tabular}{|l|l|l|}
\hline & $\begin{array}{l}\text { M/T Independenta } \\
\text { (North-Bound) }\end{array}$ & $\begin{array}{l}\text { M/V Evriali } \\
\text { (South-Bound) }\end{array}$ \\
\hline Date-Place Built & 23/05/1963- Santierul Naval Constanta, Constanta & 1971- Astilleros Armon Gijon - Gijon, Spain \\
\hline Owner & Navrom Shipping Co., Constanta & - \\
\hline Type \& Flag & Crude Oil Tanker-Romania & General Cargo-Greece \\
\hline Pilot Onboard & NO (Waiting for) & NO (Just dropped) \\
\hline Cargo & $\begin{array}{l}\text { Crude Oil-2/3 Laden-93800 tons } \\
\text { (from Es Sider/Libya) }\end{array}$ & $\begin{array}{l}\text { Fully laden- Steel Product } 7500 \text { tons } \\
\text { (from Zhdanov/Ukraine) }\end{array}$ \\
\hline DIMENSIONS (Lxbxd) & $283 \times 46 \times 22.6 \mathrm{~m}$ & $118 \times 17 \times 7.5 \mathrm{~m}$ \\
\hline Tonnage & 88690 GT & 5298 GT \\
\hline Max. Speed & 16 Knots & 14 Knots \\
\hline Engine \& Propeller & 1 Diesel Engine, Single Shaft, Single Screw & Diesel Engine, Single Screw \\
\hline
\end{tabular}


There were 45 crewmembers in Independenta and 33 in Evrialy. All of the crew of the Greek freighter survived with a great chance, while 42 of the 45 - total crewmembers of the unfortunate Romanian tanker lost their lives; only 3 of them survived. Among $42 \mathrm{crew}$ of Independenta who lost their lives, it was not even possible to find the bodies of 11 of them, including the Captain, Dorinel Mihai.

After the accident, the freighter Evriali was towed towards the Ahirkap1 anchorage area and the fire onboard the freighter was taken under control at this location. But the same could not be said for the ill-fated tanker M/T Independenta. The total amount of 94600 tons of crude oil that was onboard the giant tanker continued to burn, and tanker could not be approached in close proximity by the firefighting tugs which already had limited capacity of extinguishing range at that period of time, and, as the tanks were partly loaded, this condition made the tanker more prone to explosion due to the accumulation of gas. It was impossible to estimate the ratio of oil that was burned compared to that was spilt into the sea. The oil that was spilt into the sea began to drift towards the southern parts of the Sea of Marmara under the influence of the currents flow and caused extensive ecological damage. Thousands of dead fish went ashore on the coasts of the Anatolian part.

Surface bombs were used near the tanker's wreck, in order to keep the remaining oil on-board, the tanker, while the extinguishing boats sought to control the flames by squeezing detergents and chemicals. The fire onboard the tanker Independenta continued for several weeks, and the ship's wreck moved deeper into the bottom of the sea with ongoing explosions. The remaining ashes mixed with oil generated thick bunches which accumulated over Moda district at the Asian part of the city and led to massive air pollution. On December 6, 21 days after the accident, the fire was still going on and there was a huge explosion this day. In this explosion, the flames rose up to 350 meters towards the sky. The top of the sea became a hell of a fire and the flame began to fall out of the sky over the city. After this big explosion, the flames began to decrease relatively and on December 14, almost 1 month after the accident, the fire went out on its own and completely extinguished.

a. After- accident era: The Captain of Greek flagged ship Evriali, Capt. Alekos Adamopoulos and 7 crewmembers were arrested upon a court order after the accident. The accused were attributed to the crimes of 'carelessness, negligence and non-compliance with international navigation rules'. It was also among the accusations that the safety of Istanbul had been jeopardized and the death of 43 sailors in the Romanian tanker. The trial proceedings lasted 7 months and Captain Alekos Adamopoulos was given a 20-month sentence. However, taking into account the length of his detention at the site of Sağmalc1lar Prison and his good standing in court, this penalty was converted into a fine of 850 dollars and the captain was released. The wreckage of the tanker remained before Haydarpaşa port district for many years and continued to pose a risk for local traffic. The local ferry Hürriyet allided with the wreck on 19 April 1983 and had to be repaired at the shipyard. The task of wreck removal was given to the Navy, and subsequently Navy overhanded this job to a private sub-contractor company. In mid-November 1983, 8000 tons of wreck was removed, while the contractor firm went bankrupt. In 1986, a tender was won by Mr. Celal Sadıkoğlu for the removal of the wreck. The remaining parts of the wreck were taken to the recycling facilities in Aliağa district of Turkey on the Aegean Coast and finally, 7 years later, Istanbul got rid of this nightmare. The Romanian tanker M/T Independenta's hull and engine insurance cover was $\$ 40.26$ million. Evrialy, whose value was only 2.5 million USD, was also heavily damaged by collision and fire. There was severe damage to the starboard and the stem of Evrialy. Evrialy was sold after 6 years at Tuzla shipyards on 23 June 1986, and her fate ended up at Aliağa ship recycling facilities after this sale.

b. Accident Analysis: The following are the findings with regard to this accident (Applying the same criteria):

1. Navigational errors: According to the information in hand, The Greek freighter, Evriyali is responsible of the accident. Evriali followed the wrong course and did not carry out the proper manoeuvring in compliance with COLREG's. After the pilot had left the freighter, there should have been a head-on situation, due to which, Independenta altered her course to starboard and Evriali altered her course to port. Altering the course to Port in a head-on confrontation was used to be valid for Istanbul Port Regulation in the certain areas of Strait of Istanbul, as explained above. But not in this part of the Strait. However, it is crucial to know that whether the navigational team members onboard Evriali were aware of this fact. As the Collision Regulations ordered to 
alter the course to Starboard and Istanbul Port Regulations ordered to alter the course to Port in head-on situations, and remembering that Evriali followed the Port side of the Strait during the large portion of her passage in the Strait and crossing to starboard section from the port in front of Kizkulesi had just completed before the pilot was left, situational awareness of Evriali navigational team was -most probably- lost right before the accident.

2. Pilot onboard: Both vessels, neither Independenta nor Evriali, did not have pilot onboard at the time of the accident. Evriali had just dropped pilot 20 minutes from the accident and Independenta was waiting the pilot to arrive.

3. Meteorological/morphological difficulties: The conditions were moderate, with visibility restricted to 1.5 miles. Moderate NE winds were prevailing during the time of accident.

4. Speed: Speed of both vessels before of at the time of accident were unknown. But, from the data known, it can be said that speed of Evriali was more compared to Independenta. According to estimation, speed of Evriali was around 8 Knots and speed of Independenta was about 4-5 knots right before and during the time of the accident.

5. Left-hand side navigation and crossing areas: As explained above, confusion due to Left-hand side navigation and crossing areas might have played a role and might be attributed to this accident as the behaviour of Evriali-ship responsible of the accident- cannot be explained in another way, if not a gross negligence or intent was the case. Both vessels came into a head-on situation in which Evriali insistently altered her course to port and Independenta insistently altered her course to starboard. The area was outside of the boundaries of left-hand side navigation application area in the Strait of Istanbul. But to what extent the Captain of Evriali was aware of this situation? Having complied with the left-hand side rule at most part of the Strait, even through the advices of a pilot, might have created a confusion.

\section{Conclusions}

The Independenta-Evriali accident was a game changer in the Strait of Istanbul. After this accident, discussions were ignited regarding the safety of the Straits. At the postaccident era, the 1936 Montreux Convention was there to blame, which brought a ban on the compulsory pilotage.
And, Left-hand side navigation system was discussed. However, this issue was controversial. Some technical experts, including the pilots, said that Left-hand side navigation was compatible with the Strait of Istanbul and right-hand navigation was incompatible and would increase accidents, let aside eliminating them (Turkish Daily Newspaper Milliyet, 02 May 1982). Some veteran pilots said that although Lefthand side navigation had some advantages by being more compatible with the structure of the Strait, crossing lines at two ends of Strait could generate accidents (Barlas, 1979). In the researches carried out by the technical committee established within the Ministry of Transportation, a conclusion was reached on making changes in the maritime traffic order by providing navigation, life, property and environmental safety in the Straits. In this conclusion, the idea of changing the 'Left-hand side Navigation Order' to the 'RightHand Navigation Order' and controlling the traffic in the Strait of Istanbul was adopted. In May 1981, this report was submitted to the National Security Council (MGK). Report included the following statements:

"While entering the Strait of Istanbul from the Marmara, a vessel navigating from the right side of the Talveg line according to international rules has to pass from right to left in the area of Kizkulesi-Ortaköy Mosque line where traffic is the most intense, crossing again from Umurbank Lighthouse and leaving the Strait. Ships that will pass from the Black Sea to Marmara also apply the transitional order in the opposite direction. Within the boundaries of the Port of Istanbul, the current crossing order, which is applied in contradiction with international rules and increases the possibility of accident due to crossing areas, should be abolished and the right navigation order in accordance with international rules should be applied." (Turkish Daily "Milliyet" newspaper, 11.10.1981).

This report, prepared by the Ministry of Transportation and submitted to National Security Council, clearly set forward the conflict of National rules with the International rules. In all of the three major accidents, there were head on situations of vessels in reciprocal courses. In addition, in three of them, one of the vessels involved in the accident altered her course to starboard while the other altered her course to port. As mentioned before, action of one vessel complied with the local rule and action of the other complied with the international rule. 
After the report of Ministry of Transport, the necessary amendments were made to the Istanbul Port Regulation prepared by the Ministry of Transport and sent to the Council of State for examination. After being reviewed by the Council of State, it was published in the Official Gazette after being approved by the decision of the Council of Ministers with the number of 8/4538 dated 9 April 1982. Article 10 of the Istanbul Port Regulation, which entered into force on 1 May 1982, included:

"The sea area between the line connecting the Türkeli Lighthouse and Anadolu Lighthouse in the North and the Ahırkapı Lighthouse in the South and Kadıköy İnciburnu Lighthouse in the South, consisting of two traffic lanes and a center line separating these lanes for north and south directional traffic suitable for the passage, is called the passageway for the Strait."

According to this new system, ships crossing from the Black Sea towards the Sea of Marmara and vice versa, would pass through, from the entrance of the Strait to the exit, using the right lane in accordance with the International Rules for the Prevention of Collision at Sea.

Turkish Government, also sent an information paper to the Intergovernmental Maritime Consultative Organization (IMCO), NAV/26-Inf.9 on 26 January 1982 including a notification that the Left-hand side side navigation partly used in the Strait of Istanbul was to be abolished and new traffic order would be in full compliance with COLREG Rule 9, which regulates the traffic in narrow channels. Turkey's paper, NAV/26-Inf.9, included the following statements:

"It is decided that a new traffic order conforming to the International rules of navigation be established in the Bosphorus. The new order, which will be effective in the Bosphorus as of 1 May 1982, 09.00 GMT (12 LMT) is as follows:

1. The existing Left-hand side navigation order in the Bosphorus which is applicable between KizkulesiOrtaköy line in the south and Tarabya BurnuUmurbeyi Feneri line in the north will be abolished on 1 May 1982 at 09.00 GMT (12 LMT) and then the new order in conformity with Rule 9 of the International Regulations for Preventing Collisions at Sea, 1972, will come Into force.
1. Ships in transit from the sea of Marmara to the Black Sea or from the Black Sea, to the sea of Marmara will, in accordance with Rule 9 of the 1972 Collision Regulations navigate throughout the Bosphorus on the right-hand side of the median line (traffic separation line) and under no circumstances will they pass to the left of the mid line.

2. Ships in the course of their transit through the Bosphorus will not overtake other vessels unless they are forced to do so and will navigate inside the designated traffic lane."

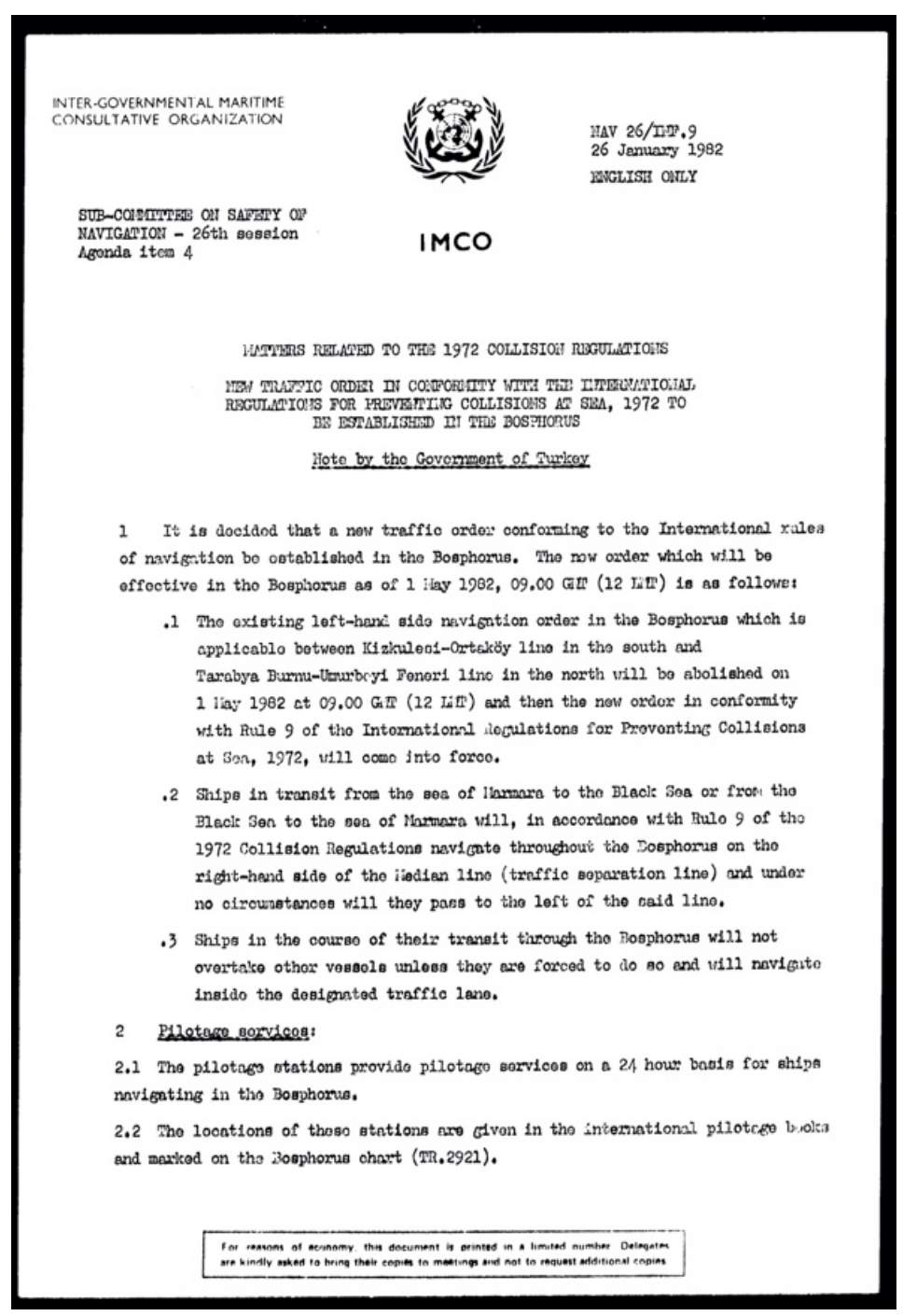

Figure 20. Informational note of Turkish Government to International Maritime Organization regarding the new traffic order in the Strait of Istanbul which took effect on 1st of May, 1982 
The new system started to be applied by 1 May 1982. In these days, 70 ships were passing per day, almost half of the number of ships that are passing today. New system increased the number of ships use pilot, which increased around 50 percent. In the new system, right hand navigation, as it was called, the first vessel to pass was the Greek flagged Dalia A., a vessel departed from Constanta, Romania and bound for Alexandria, Egypt. The first ship to pass in the new order was boarded by four Turkish Ministers including the Transportation Minister Mustafa Aysan and a plaque was given to Ship's master, Capt. Vutinas. That was the end of an era in the Strait of Istanbul, which was, to date, only sea area in the world, in which Left-hand side navigation was being used.

This was also the end of the era in which conflicting national and international rules in the Strait of Istanbul were in practice. With the establishment of Colreg Rule 9 in the Strait of Istanbul, which regulates the navigation in narrow channels, and abolishment of the left-hand side navigation, the navigational system in the Strait of Istanbul became compliant with the International system.

\section{Compliance with Ethical Standard}

Conflict of interests: The authors declare that for this article they have no actual, potential or perceived conflict of interests.

Ethics committee approval: There is no need ethics committee approval.

Financial disclosure: The authors declare that for this article there are no financial support.

\section{References}

Akten, N. (2007). Türk Boğazları ve Geleceği. Çetingil ve Kender'e 50. Çalışma Yı1ı Armağanı, p: 246.

Barlas, M. (1979). Sorular ve Sorunlar (Interview with veteran pilot Tahsin Keşmir) Turkish daily newspaper Milliyet, 19.11.1979, p. 11.

Cumpana, C. (2006). Tragedia navei "Independenţa", Editura Telegraf Advertising, p. 185-195.

IMO Web Site (2019, September 23). http://www.imo.org/en/OurWork/Environment/PollutionPre
vention/OilPollution/Pages/Background.aspx (Retrieved on 15/09/2019).

İstikbal, C. (2001). Regional Transport Demands and the Safety of Navigation in Turkish Straits, In: Problems of Regional Seas 2001: Proceedings of the International Symposium on the Problems of Regional Seas, Turkish Marine Research Foundation, p. 77, Held between 12-14 May 2001, Ataköy Marina, İstanbul, Turkey.

İstikbal, C. (2006). Turkish Straits: Difficulties and Importance of Pilotage (2006), Edit: Oral, N. and Öztürk, B. The Turkish Straits, maritime safety, legal and environmental aspects. Turkish Marine Research Foundation, Istanbul. Publication Number 25, p: 66-80. ISBN: 975-8825-15-1

İstikbal, C. (2010). Marmara Denizinde Deniz Ulaşımı ve Türk Boğazları, In: Marmara Denizi 2010 Bildiriler Kitabı, Öztürk B. Ed. TÜDAV Yayın No: 32, p. 65. ISBN: 978975-8825-22-6

İstikbal, C. (2012). Dünyada ve Türk Deniz Ticareti İçerisinde Kılavuzluğun Tarihsel Gelişimi, In: Türk Deniz Ticaret Tarihi Sempozyumu IV, Gemi Mekineleri İşletme Mühendisleri Odas1, Sena Ofset, p. 52, 16-17 April 2012.

Koçu, R.E. (1963). İstanbul Ansiklopedisi, Cilt 6, İstanbul Ansiklopedisi ve Neşriyat Koll. Şti, p. 2897.

Kvaternik, Boris (2018, July 7). http://kurziv.net/najvecahrvatska-pomorska-tragedija-i-mi-na-zalost-imamo-svojtitanic/ (Retrieved October 1, 2019).

Lameijer, J.N.F., Cockroft, A.N. (2004). A Guide to Collision Avoidance Rules, imprint of Elsevier, Sixth Edition, p.97. ISBN 0-7506-6179-8

Mihailescu, S. (2009). Petrolierul „Independenţa“ şi misterele lui, from.

https://adevarul.ro/news/eveniment/petrolierul-

independenta-misterele-lui-

1 50accc777c42d5a6638a13ff/index.html

(Retrieved on 19/11/2019).

Nautical History, OCT-DEC 2010. vol 73, edition of the Maritime Museum of Greece p. 30. 
Oğuzülgen, S. (2016). 80. Y1lında Montreux Türk Boğazları Sempozyumu, p. 182-185 . 9-10 November 2016, Bahçeşehir University, Istanbul.

Özözlü, H. (2018). Independenta Tanker Yangını, https://www.sihirlitur.com/olaylar/tanker/tanker_yazi.html (Retrieved on 19/11/2019).

Özsoy, E., Latif, M.A., Beşiktepe, Ş. (2002). The current system of the Bosphorus Strait based on recent measurements. The 2nd Meeting on the Physical Oceanography of Sea Straits, Villefranche, 15th-19th April 2002.

Soltani, A. (2009). Proactive maritime safety: concepts and applications. World Maritime University Dissertations. 254. http://commons.wmu.se/all dissertations/254 p.7 (Retrieved on 20/09/2019).
Tuğrul, S., Beşiktepe, Ş.T., Salihoğlu, İ. (2002). Nutrient exchange fluxes between the Aegean and Black Seas through the Sea of Marmara. Mediterranean Marine Science, 3(1), 33-42.

https://doi.org/10.12681/mms.256

Turkish Navy (1990). Istanbul Strait Current Profiles, Turkish Navy publications, Istanbul, Turkey.

Ünlüata, Ü. Oğuz, T. Latif, M.A., Özsoy, E. (1990). On the Physical Oceanography of the Turkish Straits, In: The Physical Oceanography of Sea Straits, L.J. Pratt (Ed.), NATO/ASI Series, 318, 26-60, Kluwer Academic Publishers, Dordrecht.

https://doi.org/10.1007/978-94-009-0677-8 2 